\title{
واقع الأمن السيبراني وزيادة فاعليته في مدارس التعليم العام بمنطقة المدينة المنورة من وجهة نظر القيادة المدرسية
}

\author{
مشاعل بنت شبيب بن مطيران الظويفري \\ ماجستير اقتصاديات التعليـم وتخطيطـهـ- وزارة التعليم- المملكة العربية السعودية \\ mashael1alzuwifri@outlook.sa
}




\title{
و اقع الأمن السيبر اني وزيادة فاعليته في مدارس التعليم العام بمنطقة المدينة المنورة من وجهة نظر القيادة المدرسية
}

\author{
مشاعل شبيب مطيران الظويفري المطيري \\ ماجستير اقتصاديات التعليم وتخطيطه- وزارة التعليم- المملكة العربية السعودية المباية \\ mashael1alzuwifri@outlook.sa
}

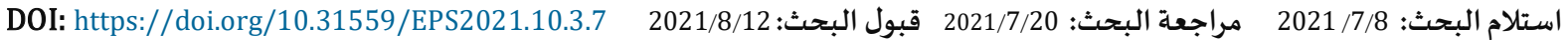

هدفت الدراسة التعرف على واقع الأمن السيبراني وآليات تفعيله في مدارس التعليم العام بمنطقة المدينة المنورة من وجهة نظر القيادة المدرسية؛ ولتحقيق ذلك؛ تم استخدام المنهج الوصفي التحليلي، وتصميم استبانة مكونة من (46) فقرة، موزعة على ثلاثة مجالات، تم توزيعها على عينة مكونة من

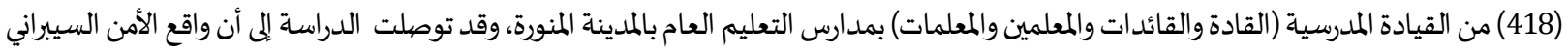
في مدارس التعليم العام بمنطقة المدينة المنورة جاء بدرجة عالية، وبمتوسط حسابي (3.62)، وبنسبة (72\%)، وأن التحديات التي تواجاء تفعيل الأمن

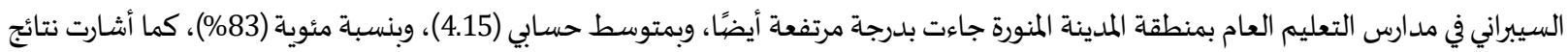

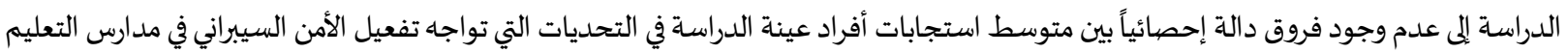

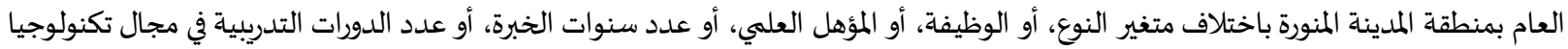

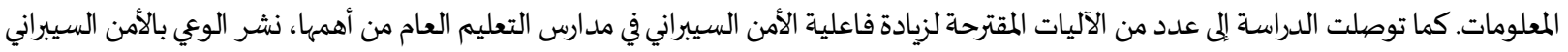

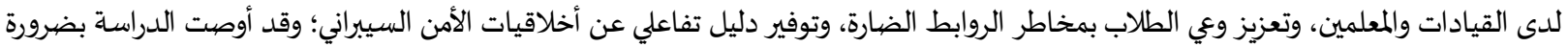
استخدام منسوبي المدارس استخدام كلمة مرور معقدة لحسابات الدخول المهمة، وعدم استخدم البريد الإلكتروني الرسمي في التسجيل والاشتراك في مواقع التواصل الاجتماعي أو التطبيقات الإلكترونية. الكلمات المفتاحية: التعليم عن بعُد؛ منصة مدرستي؛ الأمن السيبراني.

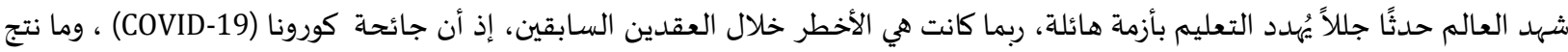

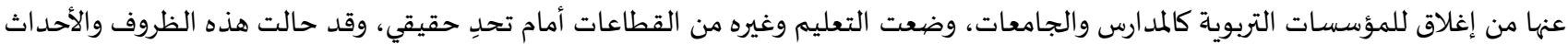

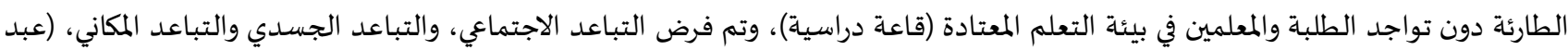

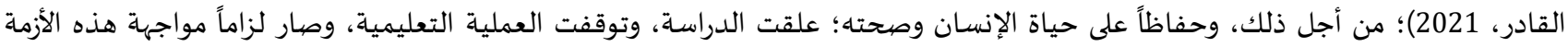

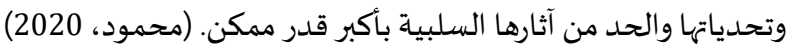

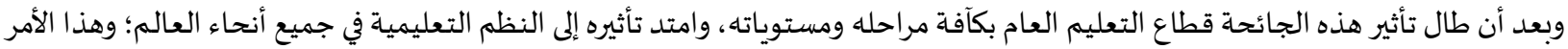

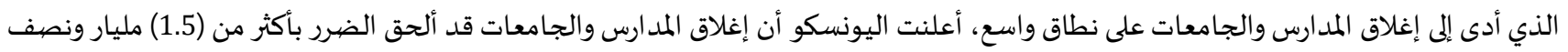

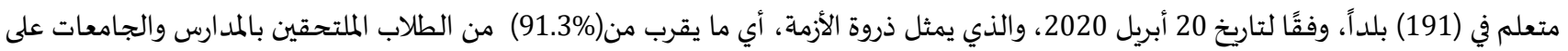

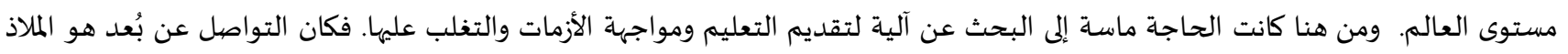


الوحيد في ظل استمرار الجائحة وتعذر التعليم التقليدي (وجهًا لوجه)، بحيث يبقى الناس في منازلهم ويمارسون حياتهم عبر وسائل التكنولوجيا

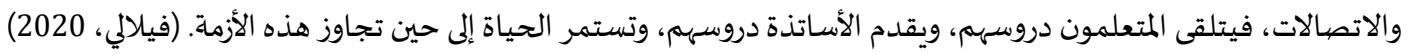

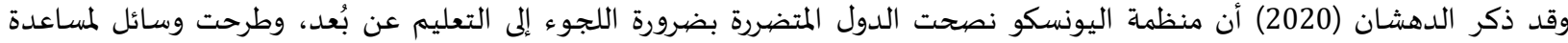

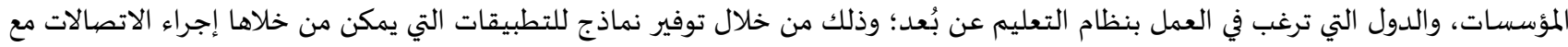

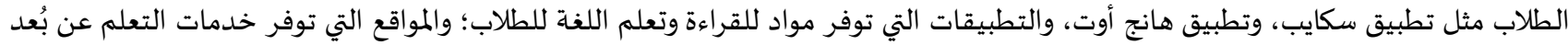

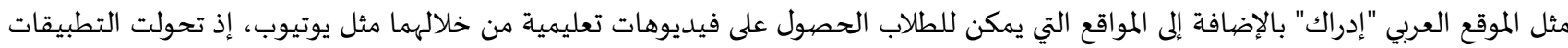

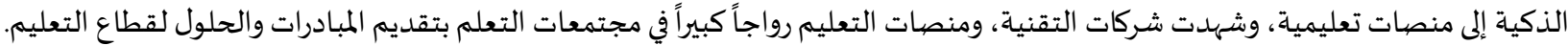

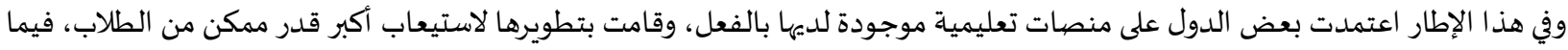

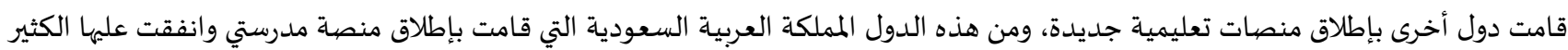

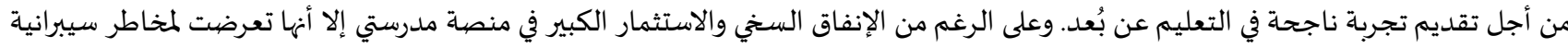

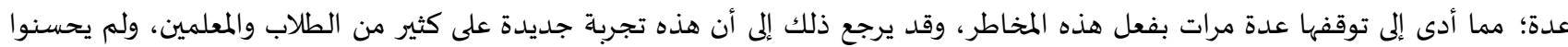

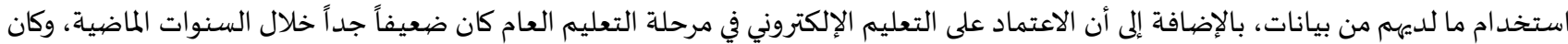

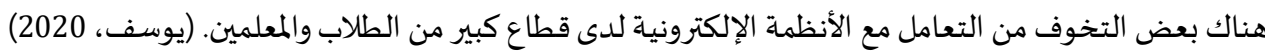

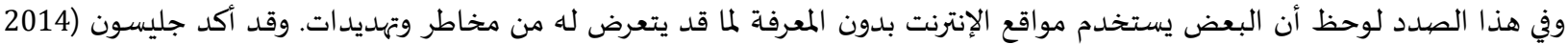

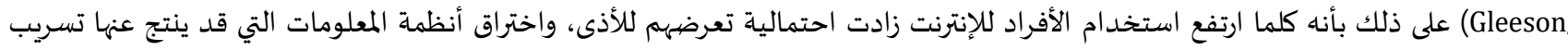

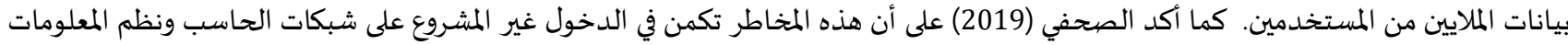

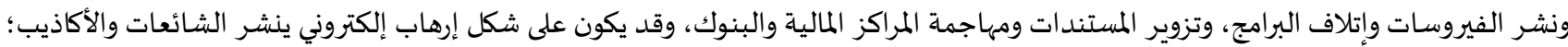

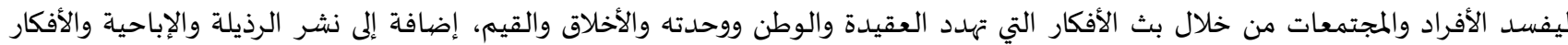
المنحرفة التي تستهدف المراهقين وتشوه ثقافتهم وأفكارهم.

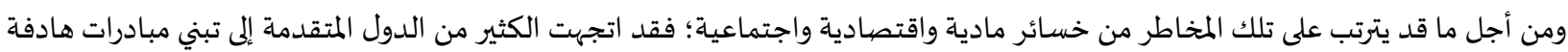

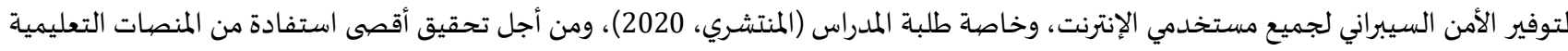

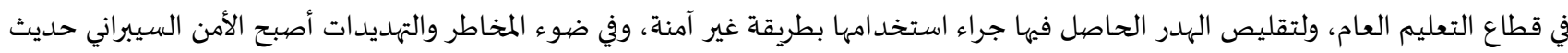

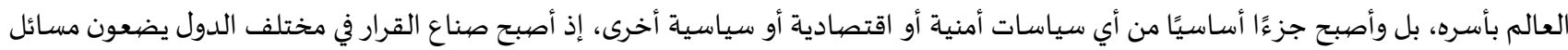

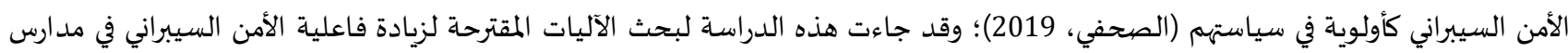
التعليم العام بمنطقة المدينة المنورة.

$$
\text { الأمن السيبر اني: }
$$

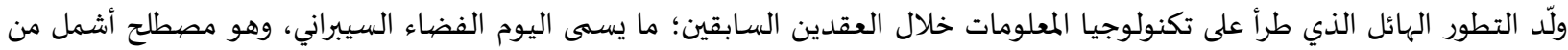

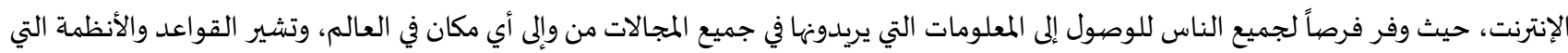

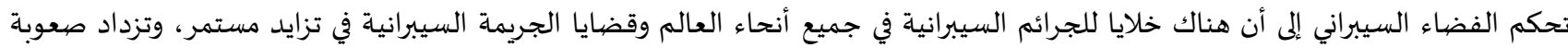

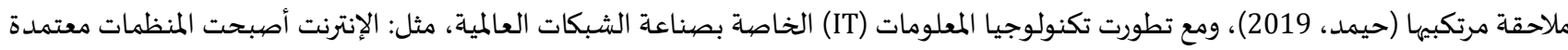

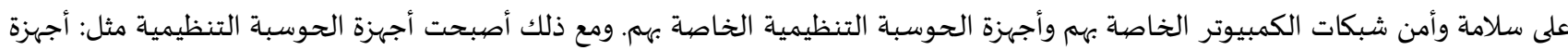
الكمبيوتر المكتبية، والمحمولة، والهواتف الذكية، أهدافًا بشكل متزايد للهجمات الإلهات الإلكترونية. (Alexander, 2017)

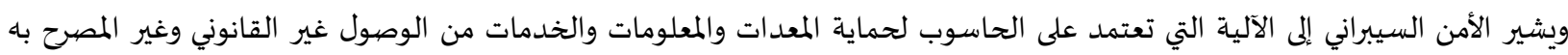

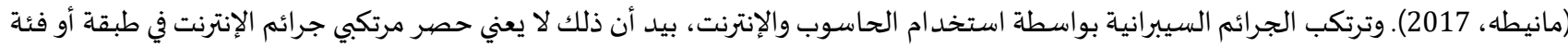

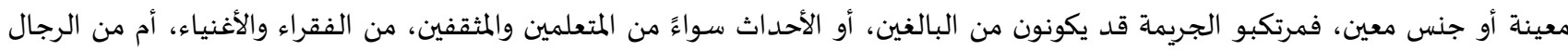

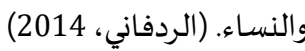

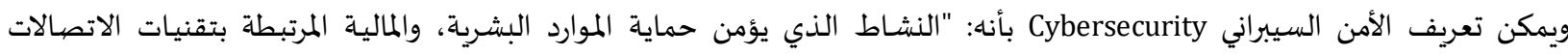

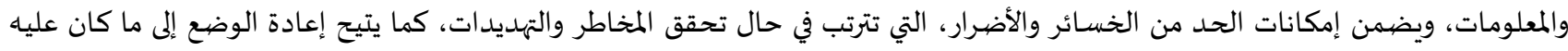

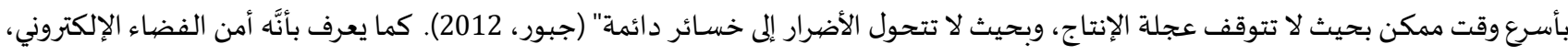

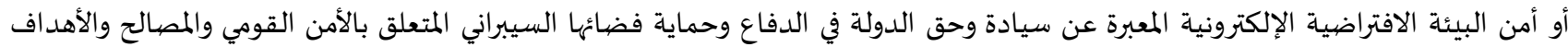

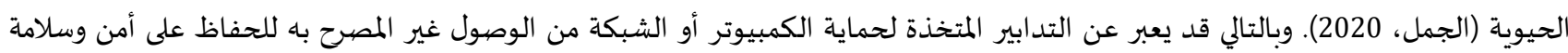

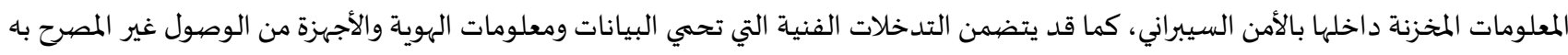


أو الضرر بما في ذلك أمن الأصهول في الفضاء الإلكتروني، وبالتالي يمكن النظر إلى الأمن السيبراني على أنه تنظيم وجمع للموارد والعمليات والهياكل

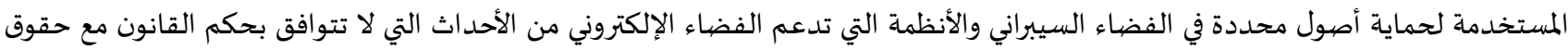

الملكية الفعلية.

وتقع مسؤولية الأمن السيبراني على جميع الأفراد، حيث يتعين على كل مستخدم اتخاذ قرارات مستنيرة حول كيفية وصهولهم إلى بياناتهم الخاصة

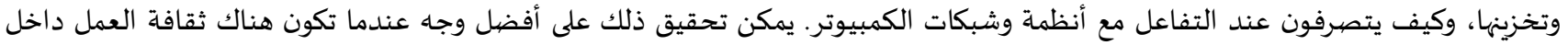

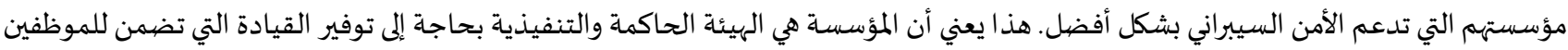

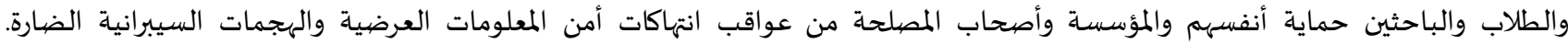

(Chapman, 2019)

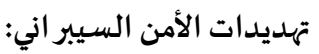

لقد تزايدت الجرائم المرتكبة بواسطة تقنيات المعلومات والاتصال، لاسيما عن طريق الإنترنت، وجسامة الخسائر المادية والبشرية، وتلك المتعلقة

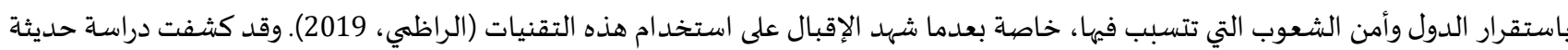

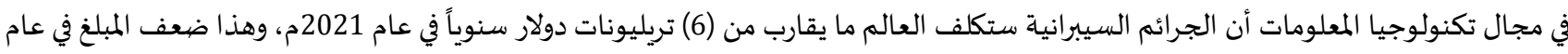

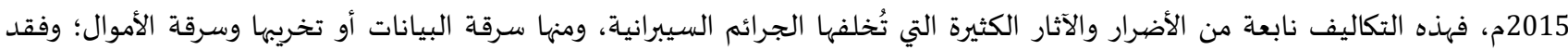

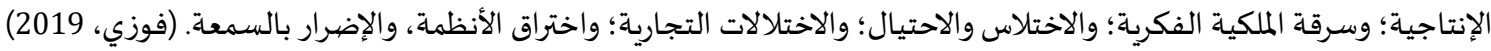

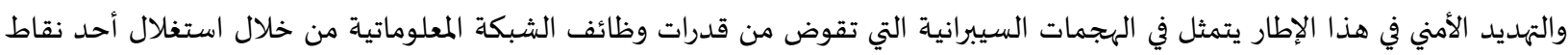

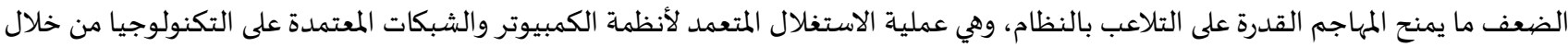

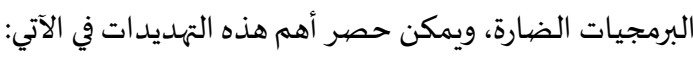

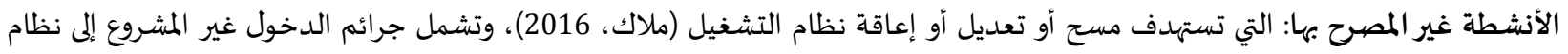

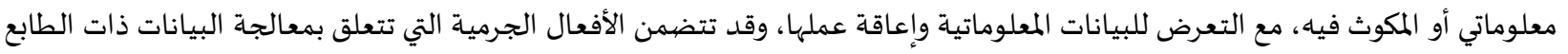

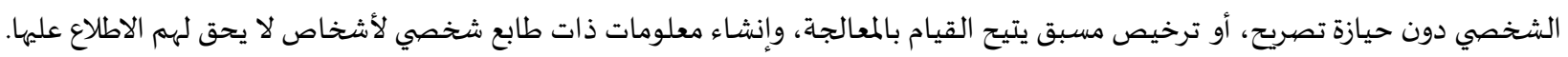

(الردفاني، 2014)

• البرمجيات الخبيثة: وتتمثل في التخمين والخداع والبرمجيات الخبيثة والنفاذ لملف تخزين كلمات المرور والتحكم بالأجهزة. (بونيف، 2019)

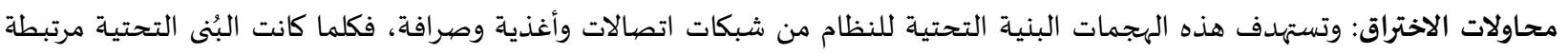

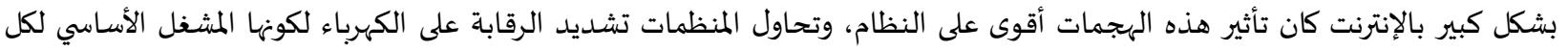

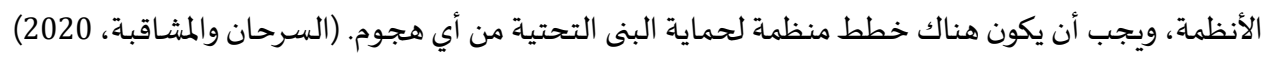

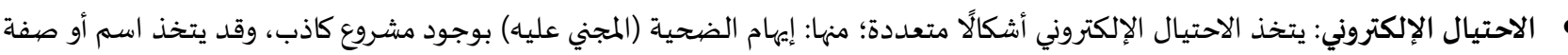

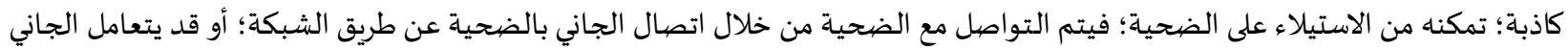

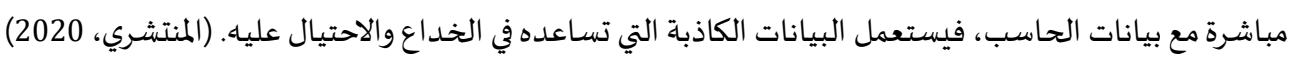

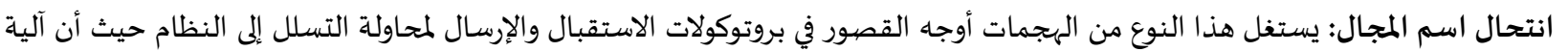

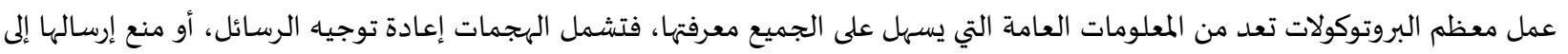
طرف معين. (السرحان والمشاقبة، 2020)

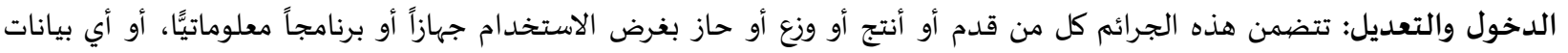

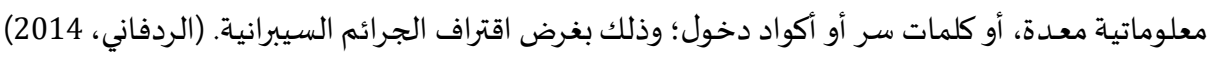

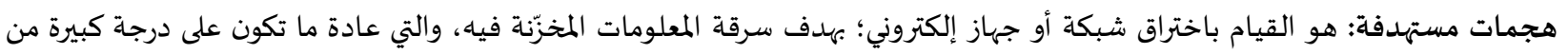

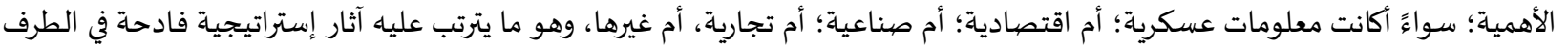
المستهدف. (العيسى، 2019)

• تسريب البيانات: أن أشهر الجرائم انتشارًا هي جرائم الدخول غير المشروع إلى البريد الإلكتروني للآخرين، وإنشاء مواقع للتشهير. (فوزي، 2019) الهندسة الاجتماعية: تشير إلى عملية تلاعب بالبشر وخداعهم بهدف الحصول على بيانات أو معلومات؛ كانت ستظل خاصة وآمنة، ولا يمكن

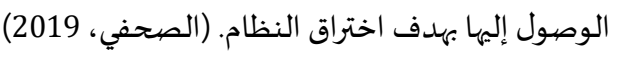

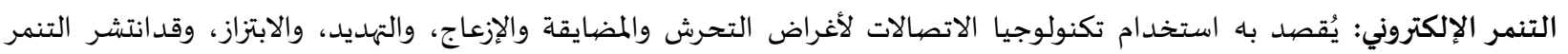
الإلكتروني كأحد أشكال المخاطر السيبرانية بصورة كبيرة مع انتشار الأجهزة اللوحية والهواتف الذكية. (المنتشري، 2020) 


\section{زيادة فاعلية الأمن السيبر اني:}

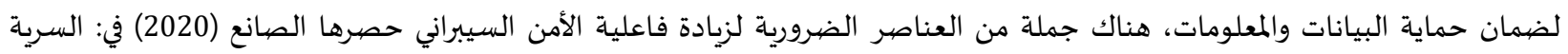

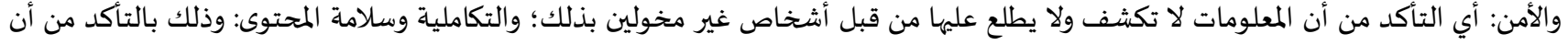

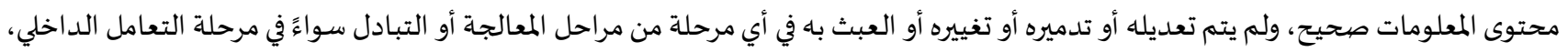

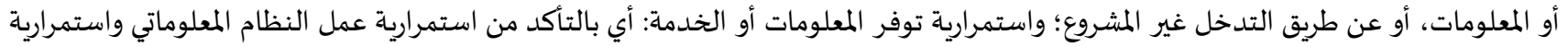

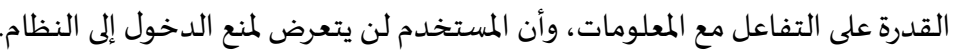

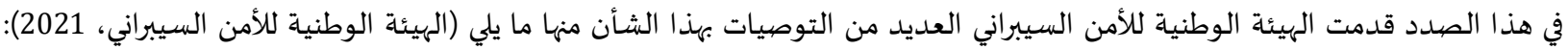

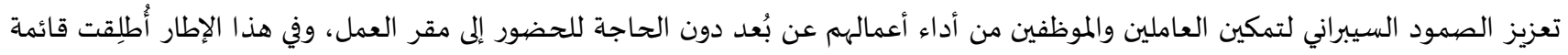

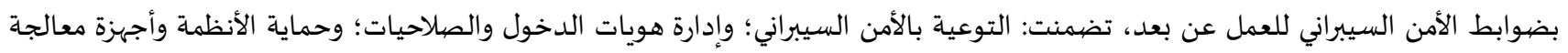

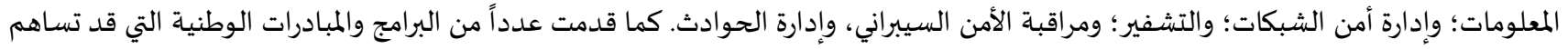
في رفع مستوى وفاعلية الأمن السيبراني مثل:

• المركز الوطني الإرشادي للأمن السيبراني: من أجل رفع مستوى الوعي بالأمن السيبراني، وتجنب المخاطر السيبرانية، وتقليل آثارها أُطلقِق المركز

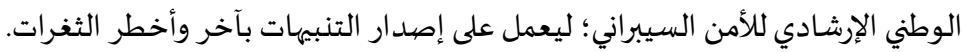

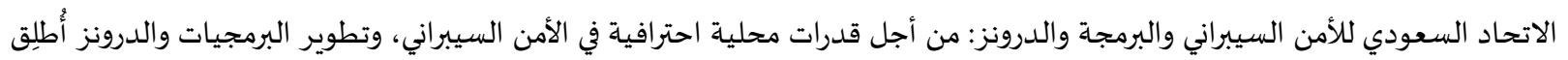

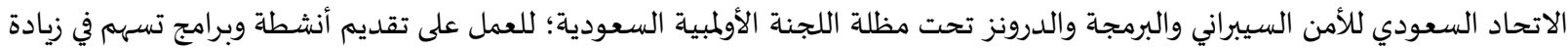

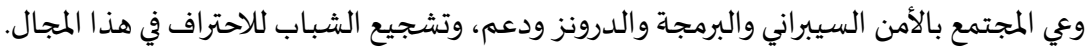

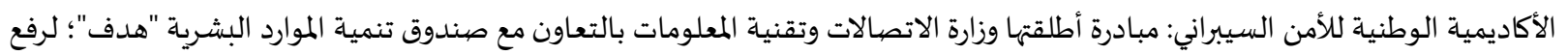

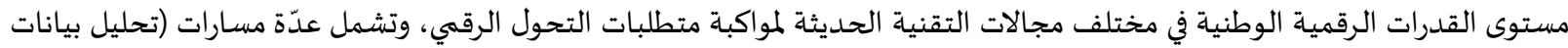

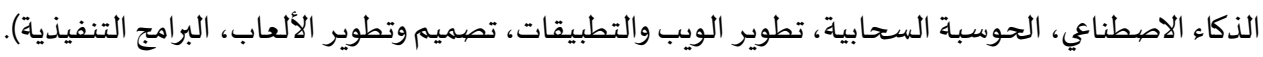

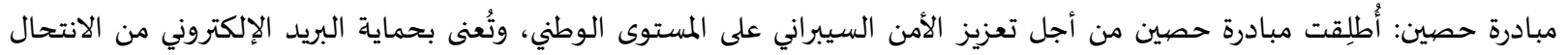

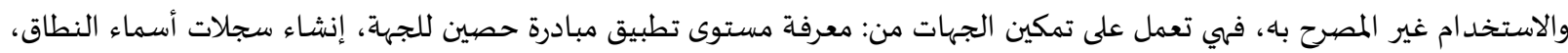

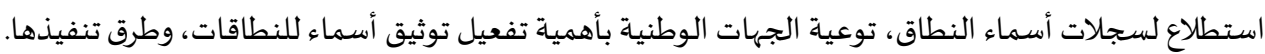

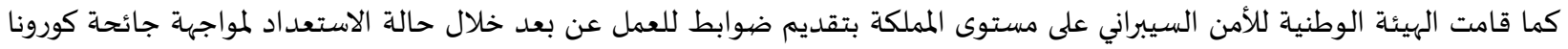
(COVID-19) التوعية بالأمن السيبراني، ويتم ذلك من خلال التعامل الأمن مع التصفح والاتصال بالإنترنت، والتعامل الأمن مع خدمات البريد الإلكتروني وإسائل التواصل الاجتمائي وغيرها. • إدارة هويات الدخول والصلاحيات، من خلال تطبيق التحقق من الهوية متعدد العناصر لعمليات العاتيات الدخول عن بُعد، والمراجعة الدورية لهويات الدخول والصلاحيات المستخدمة للعمل عن بُعد، وغيرها.

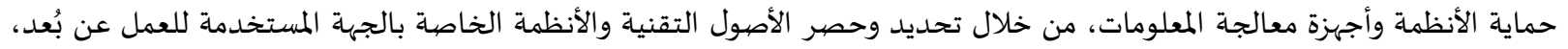

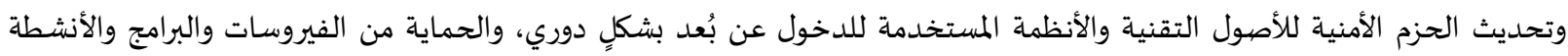

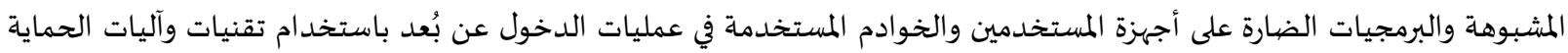
الحديثة والمتقدمة، وإدارتها بشكل آمن. المهن.

الأمن السيبر اني في وزارة التعليم: الإن

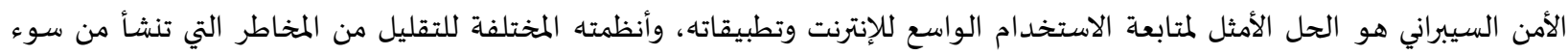

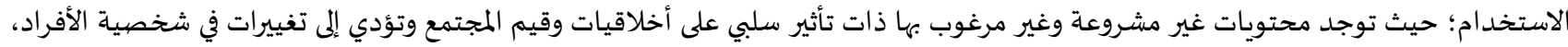

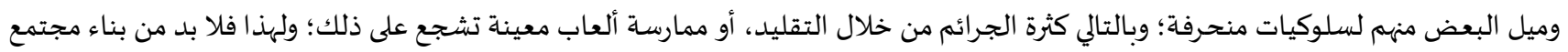

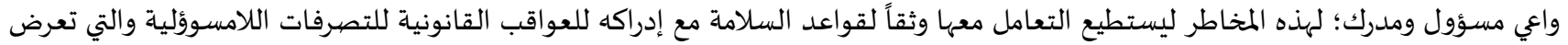

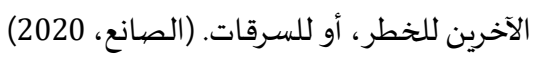

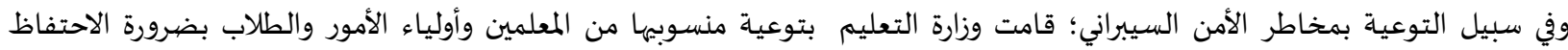

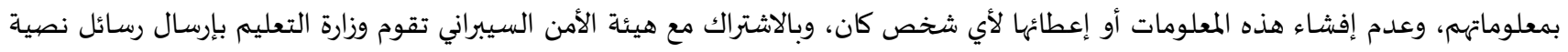

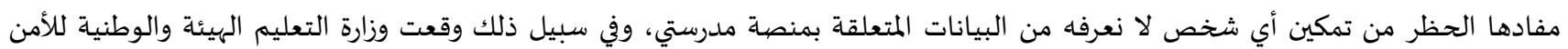


السيبراني اتفاقية؛ لتعزيز التعاون المشترك في مجالات التعليم، والبحث العلمي، والتدربب، والتوعية في مجال الأمن السيبراني؛ بما يسهم في تأهيل

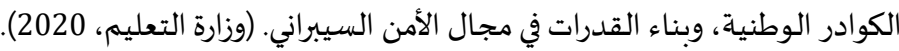
وترجع أهمية هذا التعاون الإستراتيجي مع وزارة التعليم لتحقيق أهداف الهيئة، ومستهدفات الإستراتيجية الوطنية للأمن السيبراني، المتمثلة في

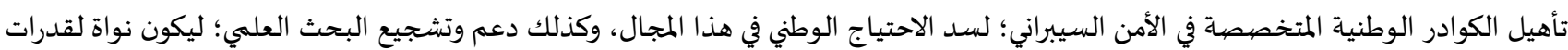

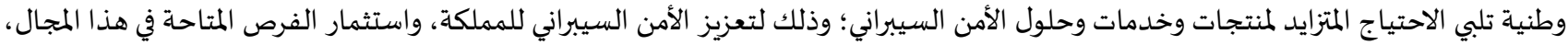

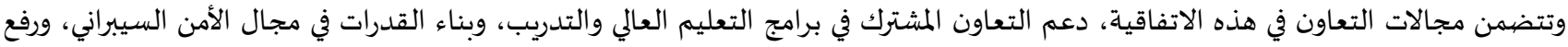

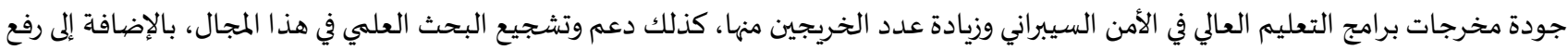

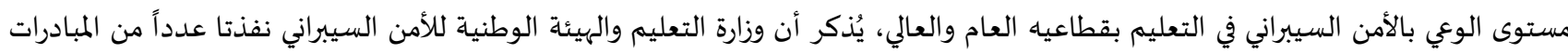

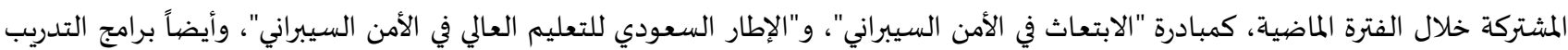
الموجهة لخريجي الجامعات السعودية. (وزارة التعليم، 2020) وقد أطلقت الهيئة الوطنية للأمن السيبراني ممثلة بالمركز الوطني الإرشادي للأمن السيبراني، بالتعاون مع وزارة وزارة التعليم حملة بعنوانيان

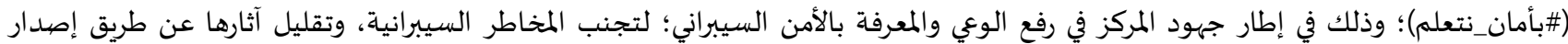

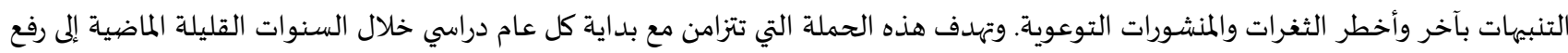

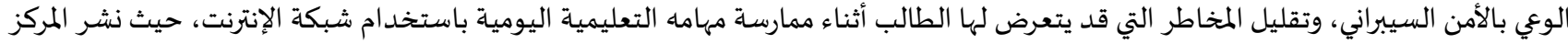

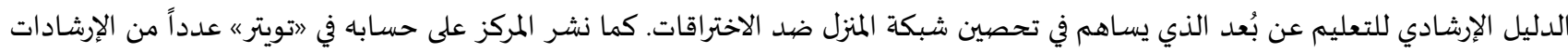

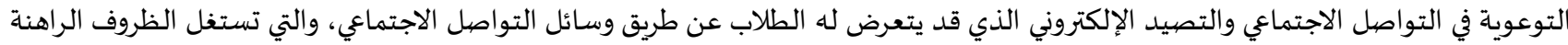

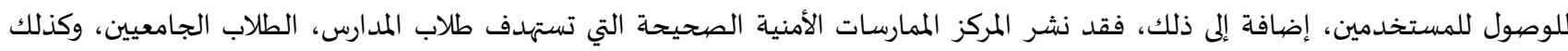
المعلمين وأعضاء هيئة التدريس والمدربين.

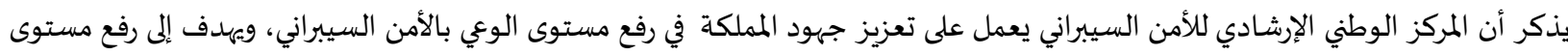

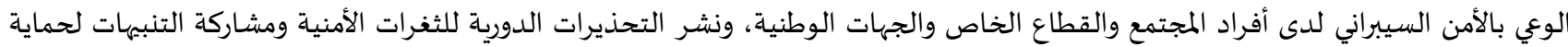

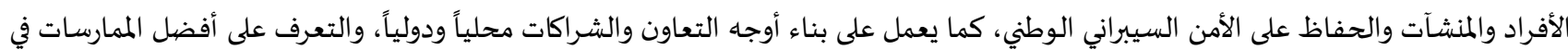

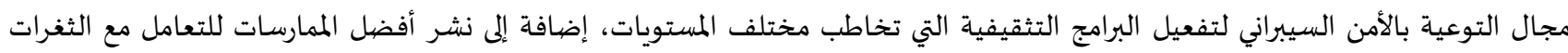

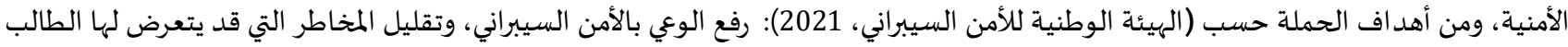

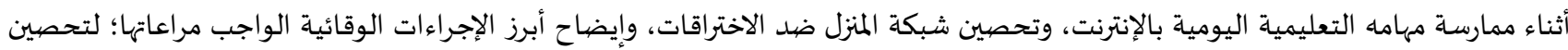

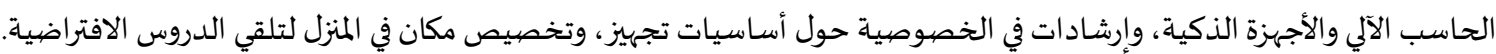

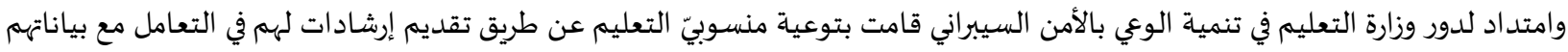

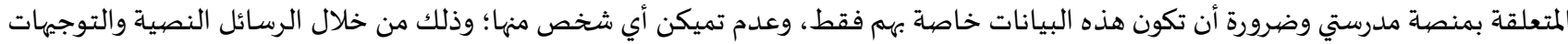

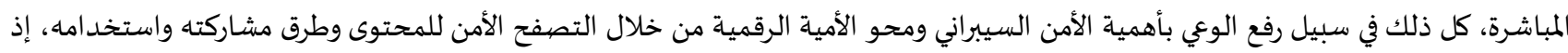

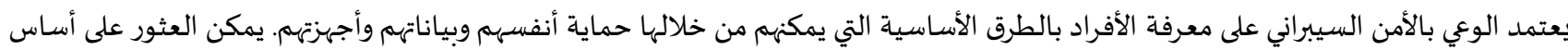

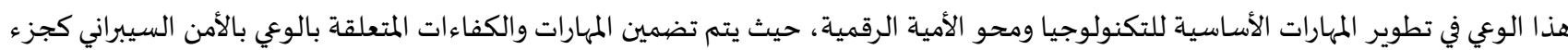

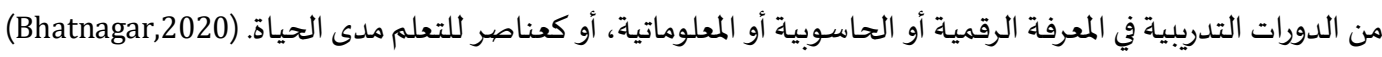

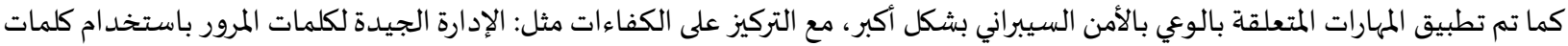

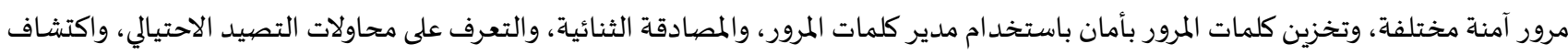
رسائل البريد الإلكتروني الضارة، واستخدام المصددر المفتوح (Frydenberg, 2020). وعلى هذا أبدت وزارة التعليم الاهتمام بالأمن السيبراني للمدرسة

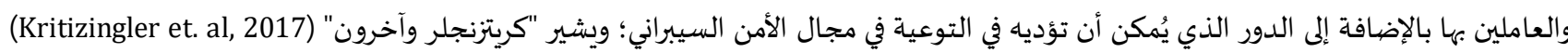

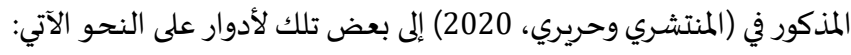
وضع خطط على مستوى المدارس بشكلٍ عام للتوعية بالأمن السيبراني؛ والتحذير من المخاطر والانتهاكات السيبرانية؛ بما يشمل الطلبة لمالية والمعلمين.

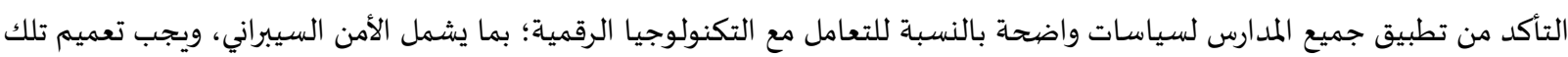

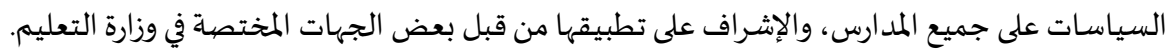

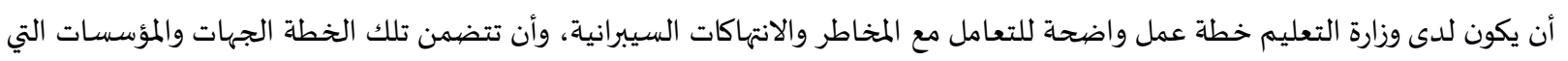

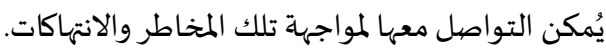


عقد دورات تدريبية لجميع المعلمين في المجالات التالية: الوعي بالأمن السيبراني لدى المعلمين، الإجراءات التي يُمكن للمعلمين اتباعها في حال وقوعهم ضحية للمخاطر والانتهاكات السيبرانية.

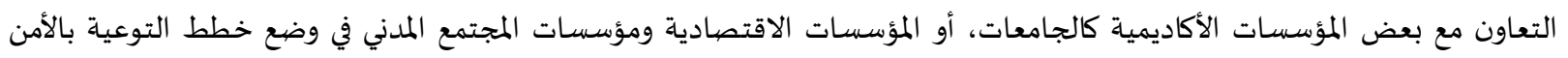

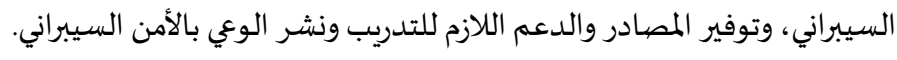

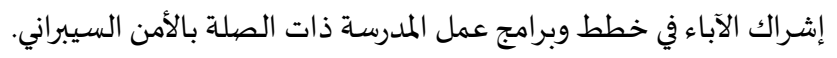

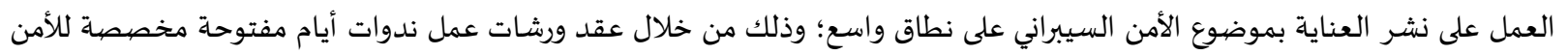

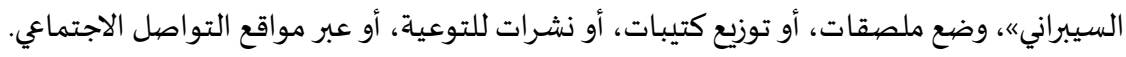
إدراج موضوع الأمن السيبراني ضمن أدلة المعلمين. • إدراج الوعي بالأمن السيبراني ضمن المهارات الحياتية اللازمة للطلبة، ومناقشته ضمن القانيان القضايا المثارة أثناء التدريس والأنشطة المدرسية. 1.1. مشكلة الدراسة:

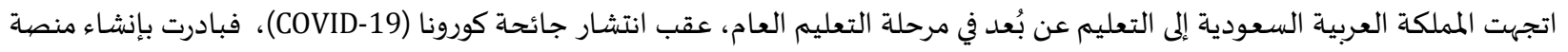

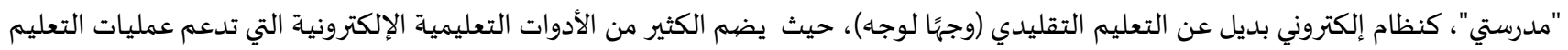

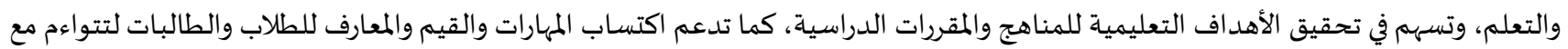

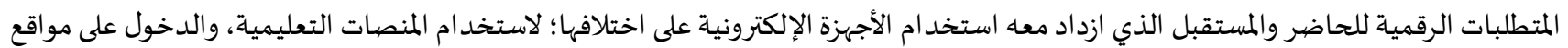
الإنترنت والبحث عن مصادر التعلم المختلفة.

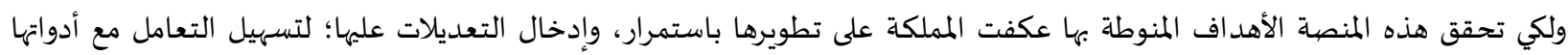

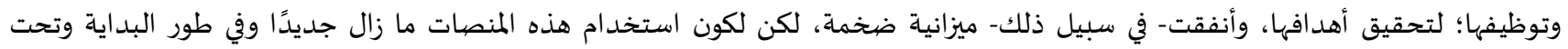

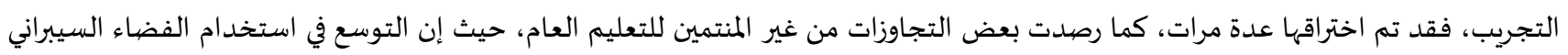

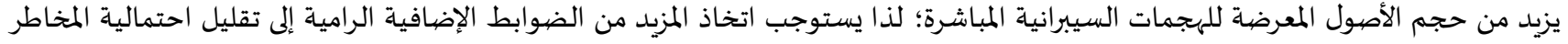

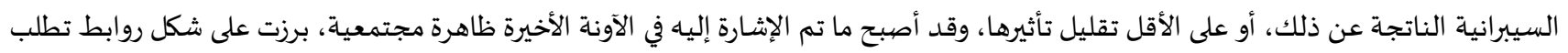

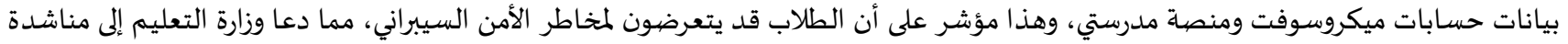

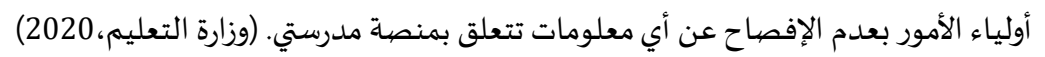

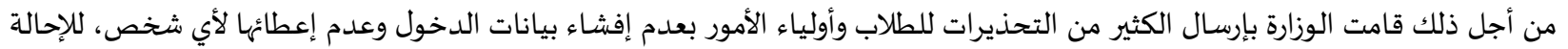

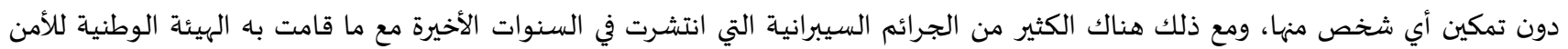

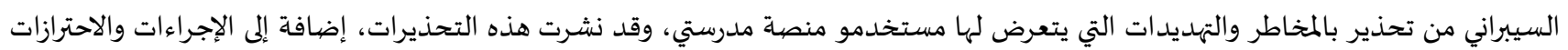

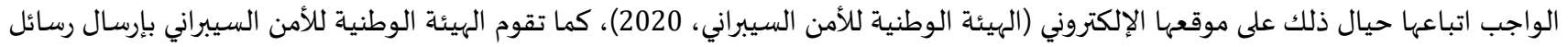

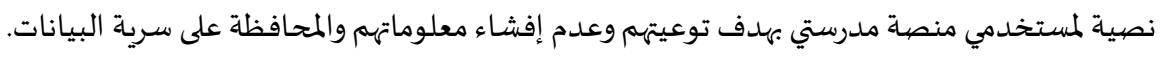

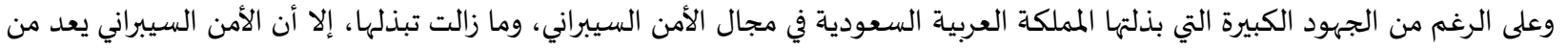

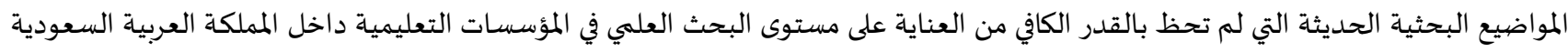

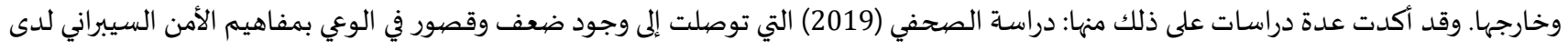

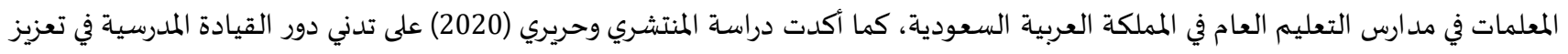

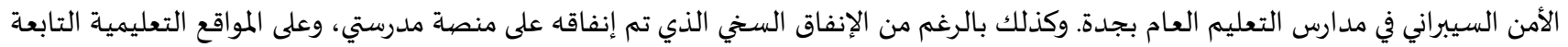

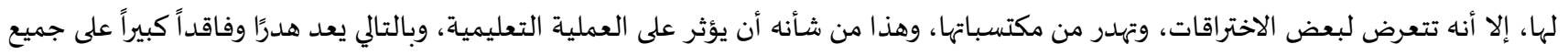

وفي ظل تدني ثقافة الأمن السيبراني للطلاب والطالبات، وعدم وعهيه بالمخاطر التي يمكن أن يتعرضوا لها من خلال استخدام الإنترنت ، فكان من

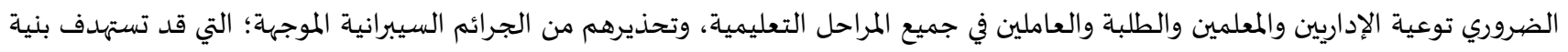

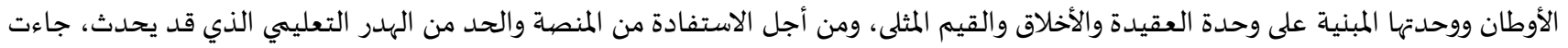

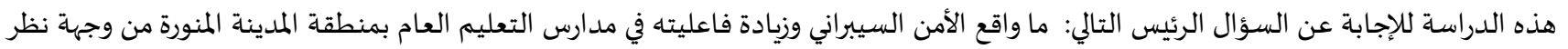


1. ما واقع الأمن السيبراني في مدارس التعليم العام بمنطقة المدينة المنورة من وجهة نظر القيادة المدرسية؟

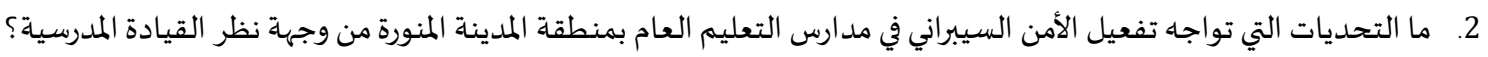
3. هل توجد فروق ذات دلالة إحصائية (0.05) بين متوسط استجابات أفراد عينة الدراسة في التحديات التي تواجاء تفعيل الأمن السيبراني في

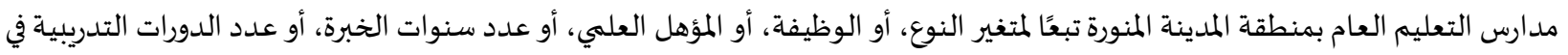

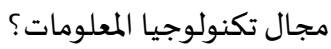

4. ما الآليات المقترحة لزيادة فاعلية الأمن السيبراني في مدارس التعليم العام بمنطقة المدينة المنورة من وجهة نظر القيادة المدرسية؟

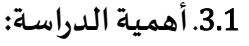

تنبع أهمية الدراسة من أهمية الموضوع الذي تناقشه، فقد أدى التقدم الرقمي المعاصر إلى تطورات هائلة غير مسبوقة في عالم التكنولوجيا، شملت جميع مجالات النشاط الإنساني، بما في ذلك الأنشطة الحياتية اليومية وصولاً إلى المجالات العلمية والتربوية والسياسية والاقتصادية، وغير

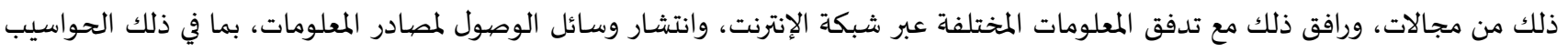
المكتبية، والمحمولة، والهواتف الذكية، مما أدى إلى ظهور العديد من المشكلات الأمنية التي تتعلق باستخدامات الإنترنت، وكذلك التوسع الكبير في

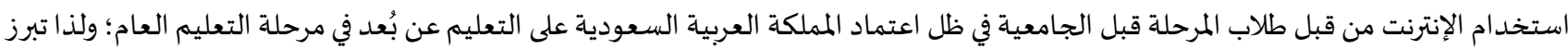
أهمية الدراسـة في النقاط الآتية: 1. إلقاء الضوء على واقع الأمن السيبراني في مدارس التعليم العام بالمملكة العربية السعودية الأمر الذي يضع أمام صناع القرار الواقع الفعلي

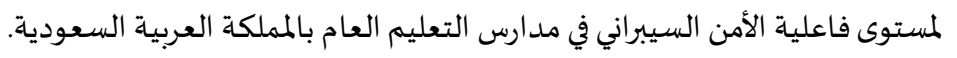

2. ق قد تسهم نتائج الدراسة الحالية في التعرف على الأمن السيبراني، وزيادة وعي المجتمع بمفهوم الأمن السيبراني، ومخاطر الانتهاكات السيبرانية.

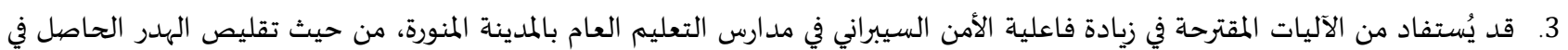

منصية مدرستي، والعمل على الاستفادة القصيوى من الإمكانيات الضخمات التي توفرها المنصية.

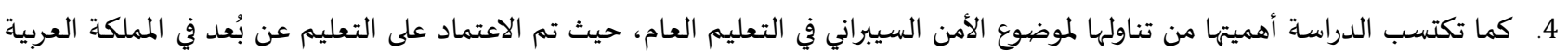
السعودية بين عامي 2020 و2021، وهذا بدوره يتطلب رفع الوعي لدى منسوبي التعليم العام بمخاطر الأمن السيبراني. 5. قد تكون الدراسة الحالية نواة لأبحاث ودراسات مستقبلية تتبنى اتجاهات حديثة فئة في التعلم.

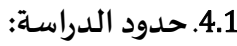

تتمثل حدود الدراسة المكانية، والبشرية، والزمنية في الآتي:

•الحدود المكانية: تتحدد الحدود المكانية في مدارس التعليم العام بالمدينة المنورة - المملكة العربية السعودية.

الحددود البشرية: تتحدد الحدود البشرية في القادة، والمعلمين، والقائدات، والمعلمات بمدارس التعليم العام بالمدينة المنورة - المملكة العربية السعودية. الحدود الزمنية: طبقت الدراسة خلال شهري فبراير ومارس 2021م -1442هـ. الحدود الموضوعية: الأمن السيبراني في المدارس:واقعه، تحدياته وأليات تفعيله.

5.1

الأمن السيبر اني (Cybersecurity): يعريف بأنه " النشاط الذي يحمي الموارد المالية والبشرية التي ترتبط بالاتصالات، ويخفف من حدة الأضرار

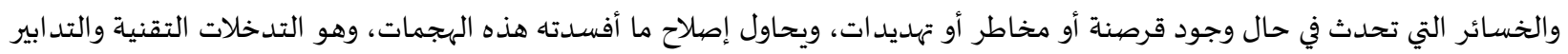

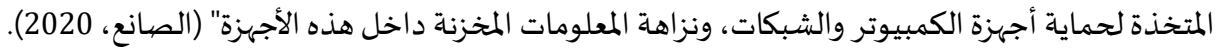

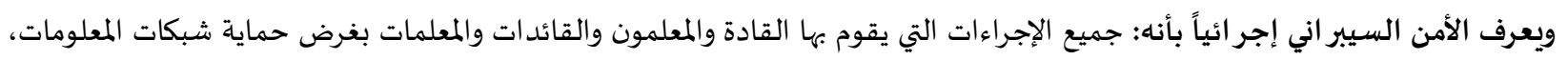
ضد كآفة الأعمال والممارسات التي تستهدف التلاعب بتلك المعلومات، وحمايتها من الاختراق ومن البرمجيات الخبيثة والفيروسات، إضافة إلى لي مقاومة التنمر، والتحكم في الوصول غير المصرح به، وغيرها من الممارسات الإلكترونية السلبية. فاعلية الأمن السيبر اني(Effectiveness of Cybersecurity): هو مدى قدرة المستخدمين على حماية بياناتهم وفاعلية الإجراءات التي يتم تنفيذها من قبل المعلمين وقادة وقائدات المدارس للتصدي لمخاطر الأمن السيبراني (الصانع، 2020). وقد تبنت الباحثة تعريف الصانع كتعريف إجرائي في هذه الدراسة.

6.1. الدراسـات السابقة: بعد الاطلاع على الأدب النظري وما تضمنها من دراسات سابقة حول موضوع الدراسة، تم اختيار مجموعة من الدراسات وثيقة الصلة بموضوع 
الدراسة الحالية، وتم ترتيبها تنازلياً من الأحدث إلى الأقدم على النحو الآتي: دراسة المنتشري (2020) والتي هدفت إلى معرفة دور القيادة المدرسية في تعزيز الأمن السيبراني في المدارس الحكومية للبنات بمدينة جدة من وجهة نظر المعلمات، واتبعت الدراسة المنهج الوصفي التحليلي، وتم إعداد استبانة، وتم تطبيقها على عينة مكونة من (420) معلمة في عدد من من

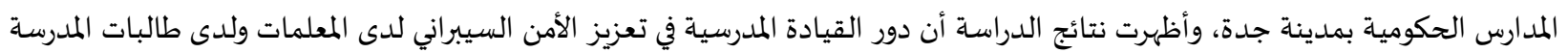

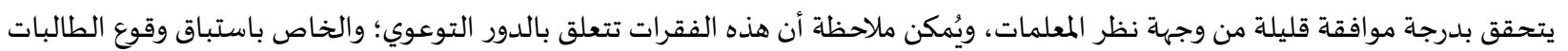

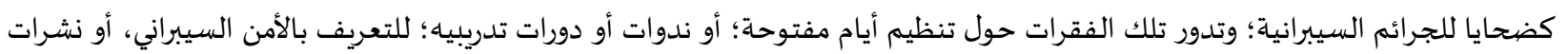

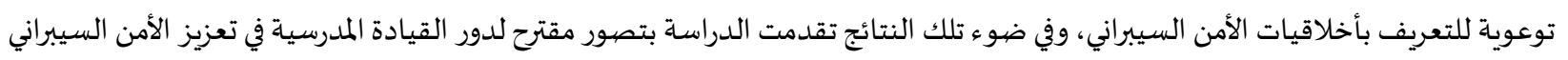

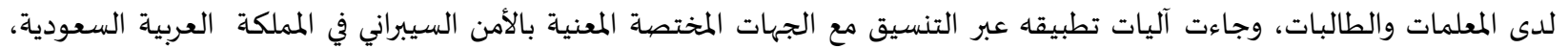

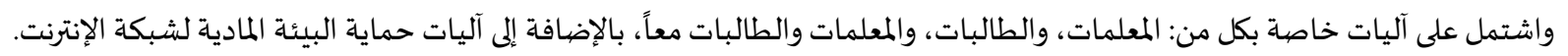
وهدفت دراسـة الصانع (2020) إلى معرفة درجة وعي المعلمين بالأمن السيبراني وعلاقته بتطبيق أساليب حديثة لحماية الطلبة من مخاطر

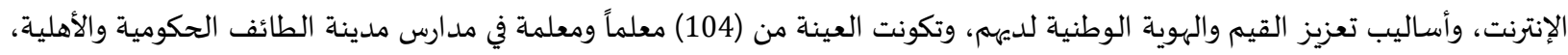

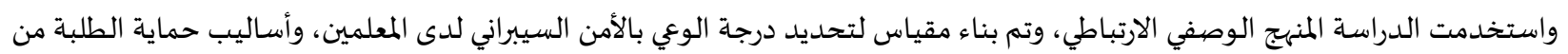

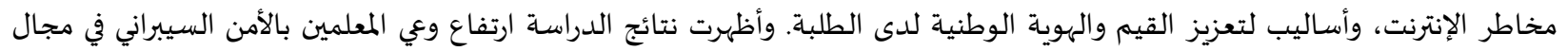

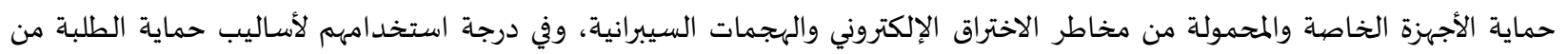

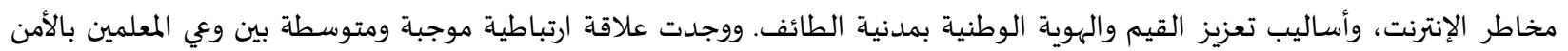

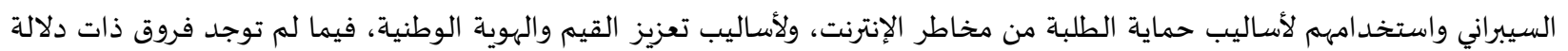

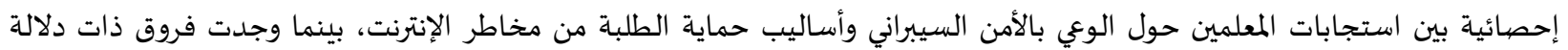

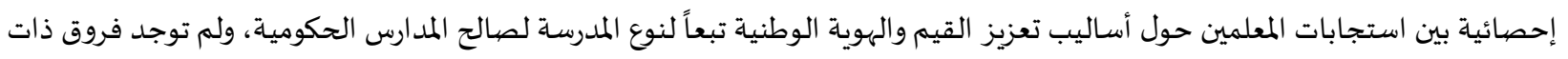

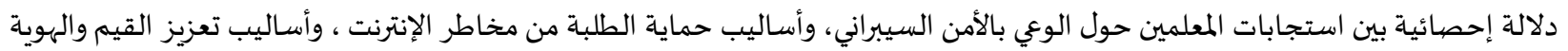

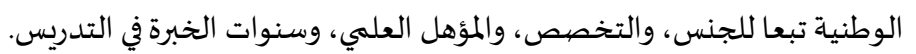
وقامت الهيئة الوطنية للأمن السيبر اني (2020) بتقصي الآثار الناجمة عن جائحة كورونا (COVID-19) على مستوى المملكة العربية

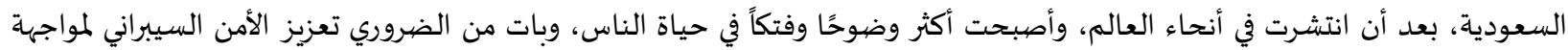

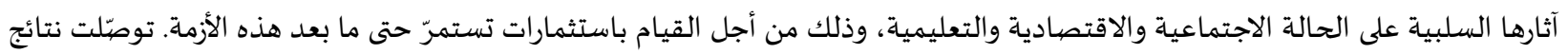

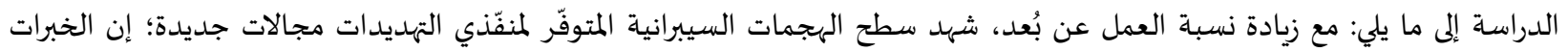

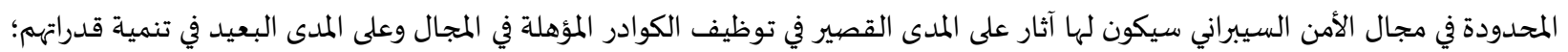

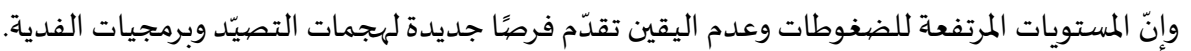
وتناولت دراسة المنتشري، وحريرى (2020) درجة وعي معلمات المرحلة المتوسطة بالأمن السيبراني في المدارس العامة بمدينة جدة من وجهة نظر

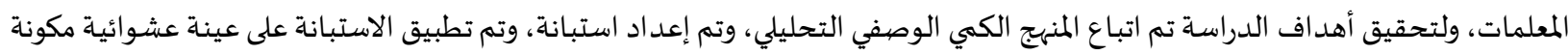

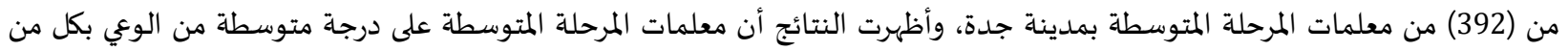

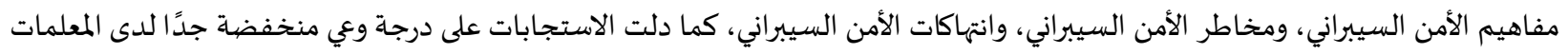

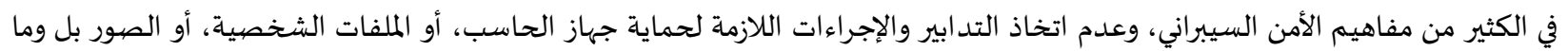

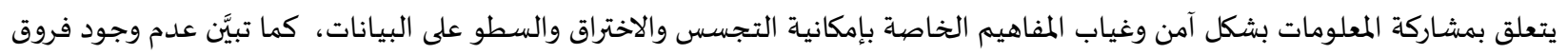

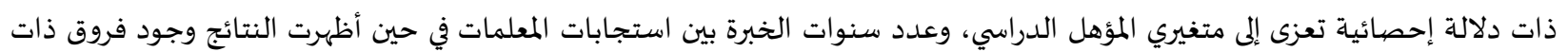

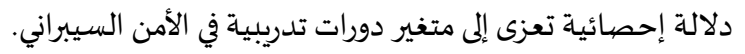
وهدفت دراسة الصحفي (2019) الكشف عن مستوى الوعي بالأمن السيبراني لدى معلمات الحاسب الآلي للمرحلة الثانوية بمدينة جدة،

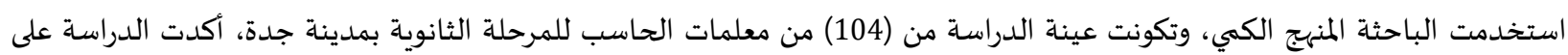

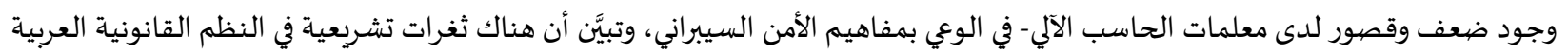

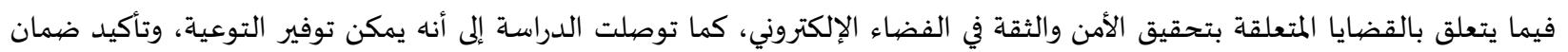

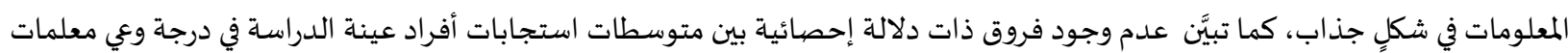

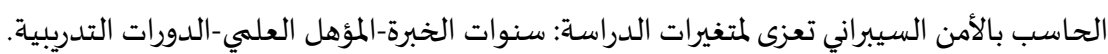
وهدفت دراسة صائغ (2018) إلى التعرف على وعي أفراد الأسرة بمفهوم الأمن السيبراني وعلاقتاه باحتياطاتهم الأمنية من الجرائم الإلكترونية،

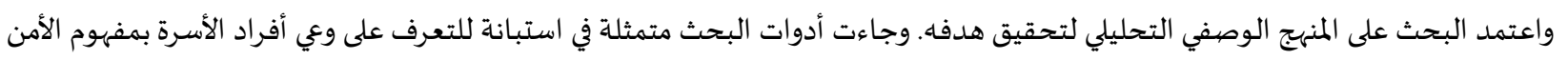


السيبراني وعلاقته باحتياطاتهم الأمنية للوقاية من الجرائم الإلكترونية، وطبقت على عينة قوامها (215) من سكان منطقة مكة المكرمة في المملكة

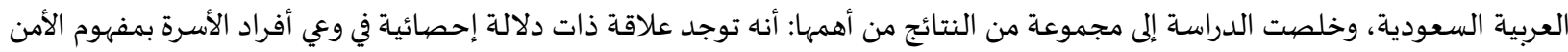
السيبراني وبين الاحتياطات الأمنية التي يتخذونها للوقاية من الجرائم الإلكترونية، كما لا توجد فروق ذات دلالة إحصائية في الممارسات التي يقوم

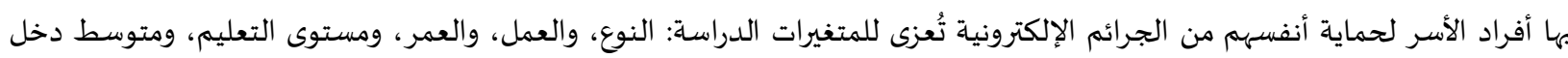
الأسرة.

استعرضت دراسة هولي وآخرين (Kurtz et al., 2018) نتائج الدراسة التي أجراها مركز أبحاث التعلم في الولايات المتحدة، وشملت عينة

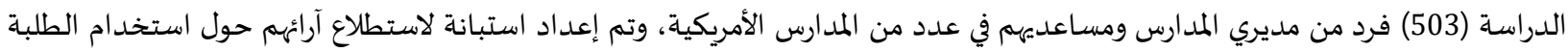

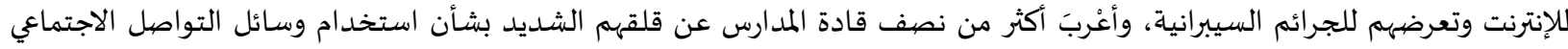

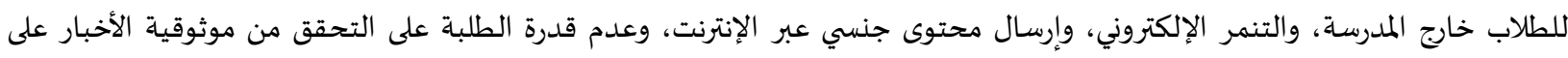

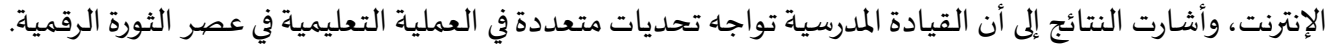
وأجرى كوريجان وروبرتسون،(Corrigan \& Robertson,2015) دراسة هدفت إلى معرفة دور قادة المدارس في مواجهة الجرائم السيبرانية في كندا، وتم استطلاع آراء تسعة من مديري المدارس الكندية، وأظهرت نتائج الدراسة أن قادة المدارس يؤدون أدون أدواراً متعددة في تعزيز الأمن

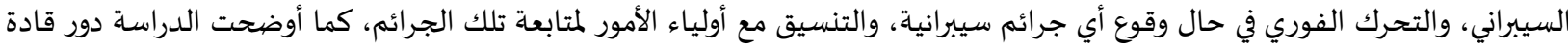

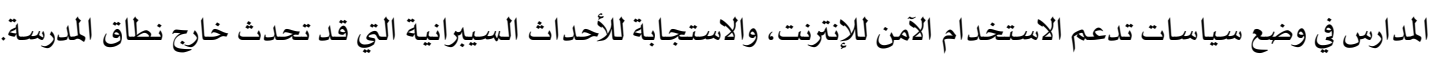
من خلال استعراض الدراسات السابقة يلاحظ أن بعضاً منها عُني بدراسة الوعي بالأمن السيبراني؛ مثل دراسة المنتشري وحريرى (2020)،

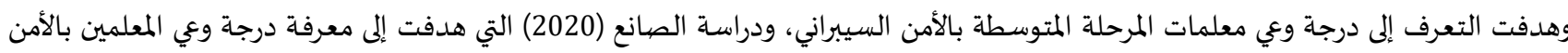

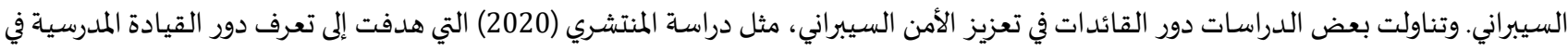

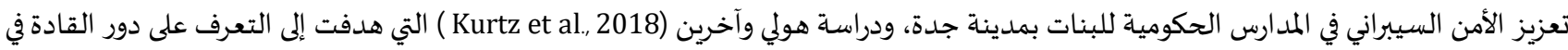

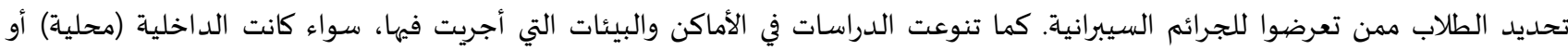

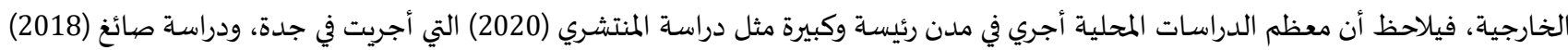

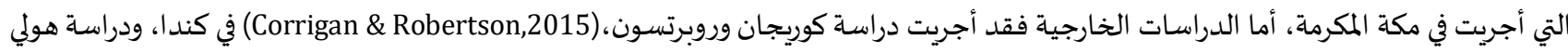
وآخرين (Kurtz et al., 2018) التي أجريت في أمريكيا. وقد اتضح أن الدراسة الحالية تتفق مع الدراسات السابقة في تناول محور الأمن السيبراني مثل

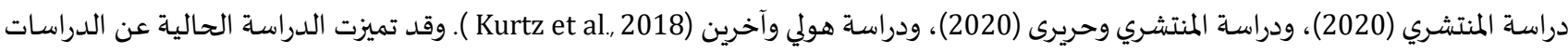
السابقة كونها تجرى في ظل الهجمات الإلكترونية المتعددة التي ظهرت مؤخراً، كما أنها تجري في المملكة العربية السعودية في ظل تبني المملكة إجراءات

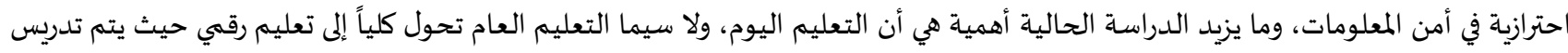
طلاب مدارس التعليم العام عن بُعد.

2. إجراءات الدراسة:

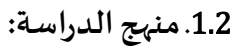

اعتمدت هذه الدراسة المنهج الوصفي التحليلي أسلوباً لها، حيث يعد المنهج الوصفي التحليلي لمناسبته لطبيعة الدراسة القائماة، ويعد هذا المنهج

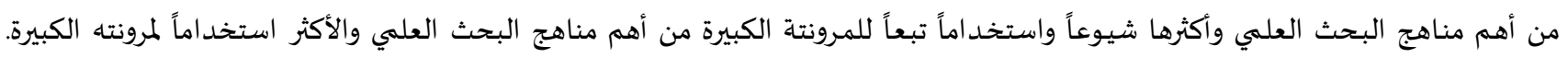

(عبيدات، 2011)

2.2 2 ت مجتمع الدراسة:

تكون مجتمع الدراسة من القادة والمعلمين والقائدات والمعلمات بمدارس التعليماتيم العام بالمدينة المنورة، المملكة العربية السعودية، وقد بلغ حجم المجتمع الكلي لعام 1442 (21.302) من القادة والمعلمين والقائدات والمعلمات.

3.2.

تم اختيار عينة الدراسـة بالطريقة العشوائية من مجتمع الدراسة المتمثل في أعضاء الإدارة المدرسية والمعلمين المعلمات بمدارس التعليم العام

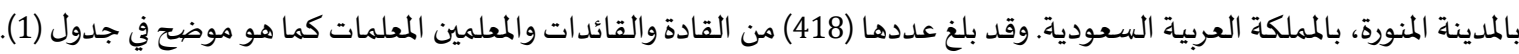




\begin{tabular}{|c|c|c|c|}
\hline 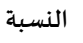 & 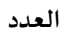 & 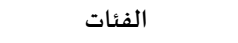 & 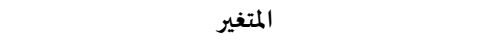 \\
\hline$\% 53$ & 223 & ذكر & 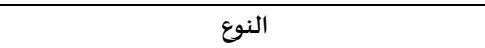 \\
\hline$\% 47$ & 195 & أنثى & \\
\hline$\% 27$ & 109 & قائد & الوظيفة \\
\hline$\% 22$ & 93 & قائدة & \\
\hline$\% 27$ & 114 & 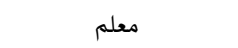 & \\
\hline$\% 24$ & 102 & 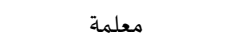 & \\
\hline$\% 45$ & 188 & بكالوريوس & المؤهل العلهي \\
\hline$\% 25$ & 106 & بكالوريوس+ دبلوم تربوي & \\
\hline$\% 21$ & 86 & ماجستير & \\
\hline$\% 9$ & 38 & 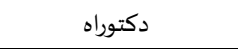 & \\
\hline$\% 16$ & 65 & أقل من 5 سنوات & عدد سنوات الخبرة الخدات \\
\hline$\% 16$ & 68 & من (5-10) سنوات & \\
\hline$\% 68$ & 285 & أكثر من 10 سنوات & \\
\hline$\% 59$ & 245 & دورتين فأقل & عدد الدورات التدريبية في مجال تكنولوجيا المعلومات \\
\hline$\% 19$ & 79 & 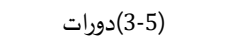 & \\
\hline$\% 22$ & 94 & أكثر من 5 دورات & \\
\hline
\end{tabular}

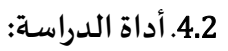

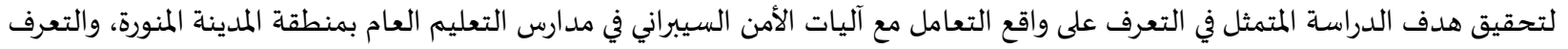

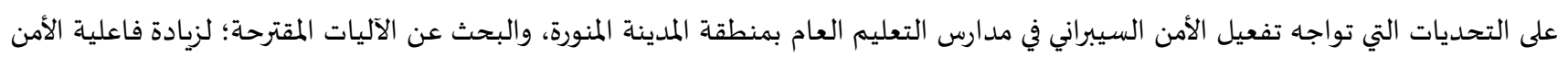

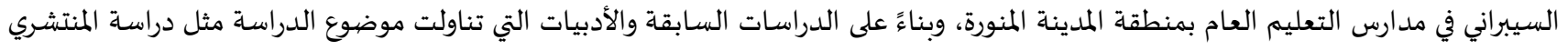

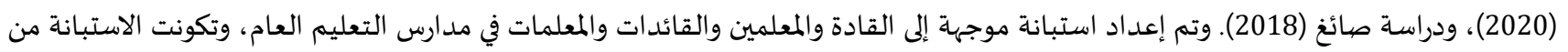

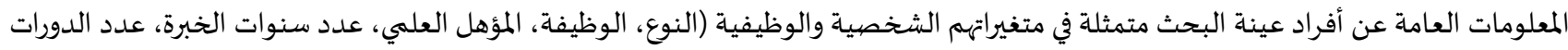

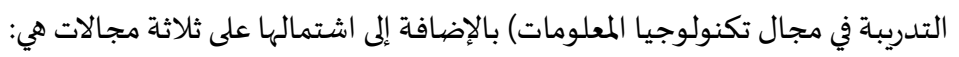

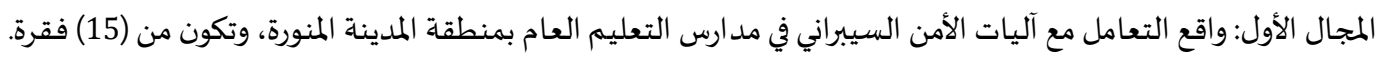
• المجال الثاني: التحديات التي تواجه تفعيل الأمن السيبراني في مدارس التعليم العام بمنطقة المدينة المنورة، وتكون من (14) فقرة.

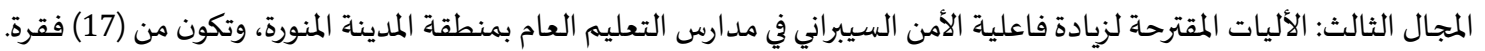

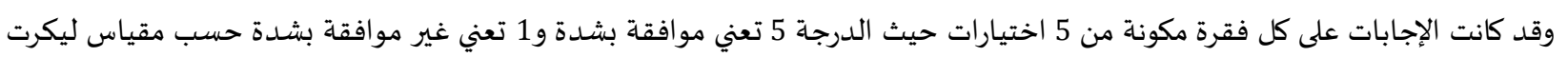
الخماسي (Scale Likert)، كما هو موضح في جدول (2) الآتي: جدول(2): مقياس ليكرت الخماسي (Scale Likert) المستخدم في الدراسة

\begin{tabular}{|c|c|c|c|c|c|}
\hline غير مو افقة بشـدة & & 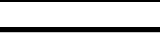 & & مو افقة بشدة & التصنيف \\
\hline 1 & 2 & 3 & 4 & 5 & الدرجة \\
\hline $1.00-1.80$ & $1.80-2.60$ & $2.60-3.40$ & $3.40-4.20$ & $4.20-5$ & متوسط الدرجة \\
\hline غير موافق بشدة & غير موافق & موافق إلى حد ما & موافق & موافقة بشدة (عالية & التقدير \\
\hline
\end{tabular}

5.2.

1.5.2. الصيدق الظاهري:

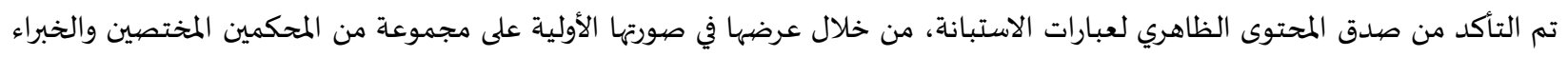

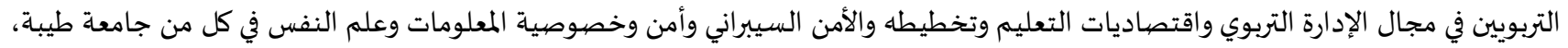

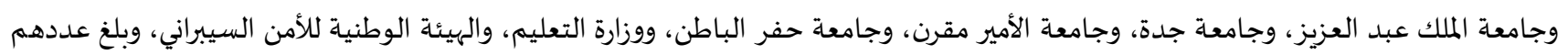

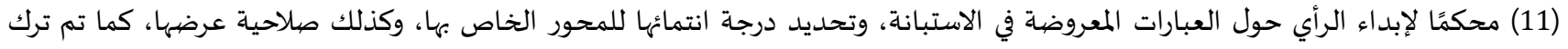

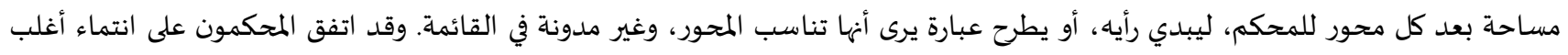

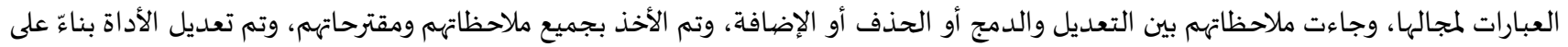


2.5.2. صددق البناء لأداة الدراسـة:

بعد التأكد من الصدق الظاهري لأداة البحث، قادت البادة الباحثة بتطبيقها ميدانياً على عينة استطلاعية عشوائية قوامها (40) من القادة والمعلمين، والقائدات والمعلمات لهم نفس خصائص العينة النهائية، كما قامت الباحثة بحساب صيدق الأداة؛ وذلك باستخدام طريقة الصددق البنائي التي تعتمد

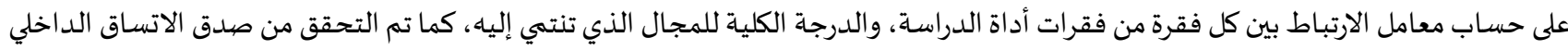

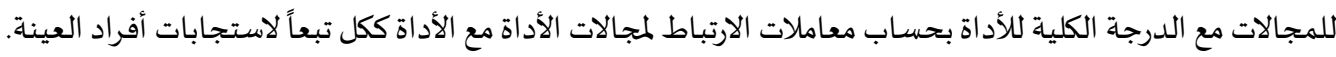

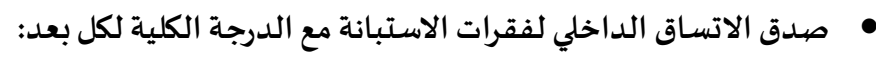

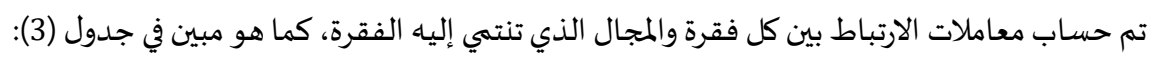

جدول (3): معامل ارتباط بيرسون (Pearson's Correlation) بين الفقرة والبعد التي تنتهي إليه

\begin{tabular}{|c|c|c|c|c|c|}
\hline \multicolumn{2}{|c|}{ المجال الثالث: الآليات المقترحة لزيادة فاعلية الأمن السيبر اني } & \multicolumn{2}{|c|}{ المجال الثاني: التحديات التي تواجه تفعيل الأمن السيبر اني } & \multicolumn{2}{|c|}{ المجال الأول:و اقع التعامل مع آليات الأمن السيبر اني } \\
\hline $\mathbf{R}$ & NO. & $\mathbf{R}$ & NO. & $\mathbf{R}$ & NO. \\
\hline $.767^{* *}$ & 1 & $.750^{* *}$ & 1 & $.414^{* *}$ & 1 \\
\hline $.857^{* *}$ & 2 & $.782^{* *}$ & 2 & $.426^{* *}$ & 2 \\
\hline $.721^{* *}$ & 3 & $.647^{* *}$ & 3 & $.477^{* *}$ & 3 \\
\hline $.765^{* *}$ & 4 & $.698^{* *}$ & 4 & $.727^{* *}$ & 4 \\
\hline $.905^{* *}$ & 5 & $.756^{* *}$ & 5 & $.684^{* *}$ & 5 \\
\hline $.696^{* *}$ & 6 & $.767^{* *}$ & 6 & $.588^{* *}$ & 6 \\
\hline $.740^{* *}$ & 7 & $.824^{* *}$ & 7 & $.637^{* *}$ & 7 \\
\hline $.846^{* *}$ & 8 & $.654^{* *}$ & 8 & $.741^{* *}$ & 8 \\
\hline $.838^{* *}$ & 9 & $.827^{* *}$ & 9 & $.739^{* *}$ & 9 \\
\hline $.772^{* *}$ & 10 & $.616^{* *}$ & 10 & $.774^{* *}$ & 10 \\
\hline $.843^{* *}$ & 11 & $.498^{* *}$ & 11 & $.840^{* *}$ & 11 \\
\hline $.793^{* *}$ & 12 & $.635^{* *}$ & 12 & $.743^{* *}$ & 12 \\
\hline $.860^{* *}$ & 13 & $.653^{* *}$ & 13 & $.701^{* *}$ & 13 \\
\hline $.794^{* *}$ & 14 & $.333^{*}$ & 14 & $.680^{* *}$ & 14 \\
\hline $.811^{* *}$ & 15 & & & $.707^{* *}$ & 15 \\
\hline
\end{tabular}

* * دالة إحصائياً عند مستوى معنوية 0.01، * دالة إحصائياً عند مستوى معنوية 0.05.

يتضح من جدول (3) أن جميع قيم معاملات الارتباط موجباة، وجميعها ذات دلالة إحصائية عند مستوى الدلالة (0.01)، عدا الفقرة رقم (14)

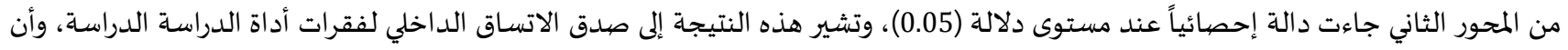

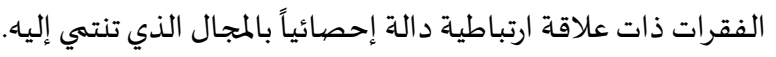

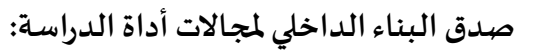

تم حساب معاملات الارتباط باستخدام معامل ارتباط بيرسون (Pearson's Correlation) للمجالات مع الدرجة الكلية للاستبانة تبعاً لاستجابات أفراد العينة، كما هو مبين في جدول (4) التالي.

جدول (4): معامل ارتباط بيرسون (Pearson's Correlation) بين البعد والدرجة الكلية للاستبانة

\begin{tabular}{|c|c|c|c|}
\hline معامل بيرسون & 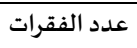 & المجال & $\begin{array}{c} \\
\end{array}$ \\
\hline $.631^{* *}$ & 15 & المجال الأول: واقع التعامل مع آليات الأمن السيبراني في مدارس التعليم العام & 1 \\
\hline $.513^{* *}$ & 14 & المجال الثاني: التحديات التي تواجه تفعيل الأمن السيبراني في مدارس التعليم العام & 2 \\
\hline $.701^{* *}$ & 17 & المجال الثالث: الآليات المقترحة؛ لزيادة فاعلية الأمن السيبراني في مدارس التعليم العام & 3 \\
\hline
\end{tabular}

** * دال إحصائياً عند مستوى الدلالة (0.01).

يتضح من جدول (4) أن قيم معاملات الارتباط لمجالات أداة الدراسة مع الدرجة الكلية لها كانت دالة إحصائيًا عند مستوى الدلالة (0.01)،

وجميعها قيم موجبة.

6.2 ثبات أداة الدراسـة:

يدل الثبات على " المدى الذي تظل فيات أداة أداة القياس ثابتة في قياس ما تقيس" (سليمان وأبو علام، 2010، ص596). وللتحقق من ثبات أداة الدراسة تم حساب معامل الاتساق الداخلي معادلة كرونباخ ألفا (Cronbach's ALPHA)، وجاءت النتائج، كما هو مبين في جدول (5) الآتي:

\begin{tabular}{|c|c|c|}
\hline معامل كرونباخ الفا & 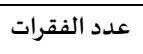 & المجال \\
\hline 0.901 & 15 & المجال الأول: واقع التعامل مع آليات الأمن السيبراني في مدارس التعليم العام \\
\hline 0.904 & 14 & المحور الثاني: التحديات التي تواجه تفعيل الأمن السيبراني في مدارس التعليم العام \\
\hline 0.958 & 17 & المحور الثالث: الآليات المقترحة؛ لزيادة فاعلية الأمن السيبراني في مدارس التعليم العام \\
\hline 0.893 & 46 & الاستبانة ككل \\
\hline
\end{tabular}


يتضح من جدول (5) أن أداة الدراسة ككل تتمتع بدرجة ثبات عالية، فقد بلغت قيمة معامل كرونباخ ألفا (Cronbach's ALPHA) للاستبانة

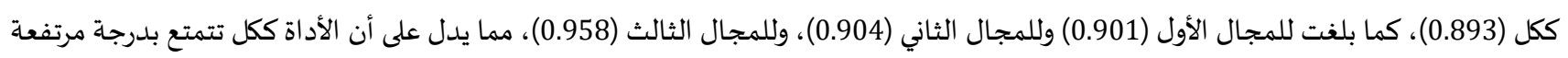
من الثبات ويمكن الموثوق في نتائجها.

3. نتائج الدراسـة ومناقشتها: 1.3. النتائج المتعلقة بالسؤال الأول: للإجابة على هذا السؤال والذي ينص على: ما و اقع الأمن السيبر اني في مدارس التعليماليم العام بمنطقة المدينة المنورة من وجهة نظر القيادة المدرسية؟

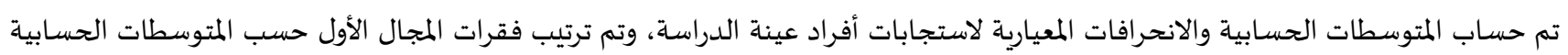
تنازلياً كما هو موضح في جدول (6). جدول (6): المتوسطات الحسابية والانحر افات المعيارية والنسبة المئوية لاستجابات أفراد عينة الدراسة على المحور الأول "و اقع التعامل مع آليات الأمن

\begin{tabular}{|c|c|c|c|c|c|c|}
\hline \multicolumn{7}{|c|}{ السيبر اني" } \\
\hline الاستجابة & الترتيب & النسبة المئوية & 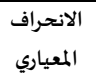 & الحسابي & الفقرات & رقم الفقرة \\
\hline عالية & 1 & $80 \%$ & 0.79 & 4.02 & أحرص على استخدام متصفح آمن للإنترنت. & 8 \\
\hline عالية الية & 2 & $79 \%$ & 0.79 & 3.94 & موقعها الرسمي (منصة مدرستي). & 3 \\
\hline 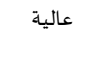 & 3 & $79 \%$ & 0.83 & 3.93 & الاختراقدم برمجيات معتمدة وموثوقة؛ لحماية الحاسب من & 11 \\
\hline عالية & 4 & $78 \%$ & 0.95 & 3.90 & ألحترونية مجهولة المصديدر. ألمرفيّ مرفقات أو روابط مرفقة مع رسائل & 4 \\
\hline عالية & 5 & $77 \%$ & 0.98 & 3.85 & أحدر على عدم الإفصاح عن كلمة المرور الخاص بي لأي & 12 \\
\hline عالية & 6 & $75 \%$ & 0.89 & 3.75 & بياناتي الشخترية والمالية. & 10 \\
\hline عالية & 7 & $75 \%$ & 0.97 & 3.74 & بشكيد دوري. ألمدرسة من منسوبها تغيير كلمة المرور الخاصة ههم & 1 \\
\hline عالية الية & 8 & $73 \%$ & 1.06 & 3.65 & للا أستخدم التطبيقات المجهولة التي تقدم خدمات مجانية & 9 \\
\hline عالية & 9 & $71 \%$ & 1.12 & 3.57 & أالتجنب إرسال معلوماتي الشخصية عبر الرسائل أو البريد & 6 \\
\hline متوسطة & 10 & $68 \%$ & 1.09 & 3.39 & 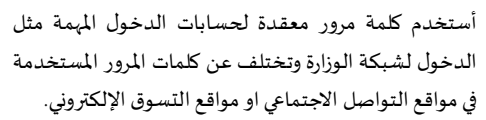 & 2 \\
\hline 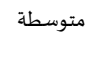 & 11 & $67 \%$ & 1.21 & 3.36 & 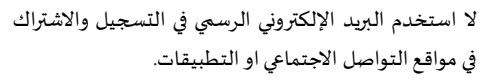 & 7 \\
\hline متوسطة & 12 & $67 \%$ & 1.21 & 3.35 & أحتفظ بنسخة الستبة أتياطية من ملفاتي في ذاكرة خارجية، & 14 \\
\hline متوسطة & 13 & $67 \%$ & 1.16 & 3.33 & 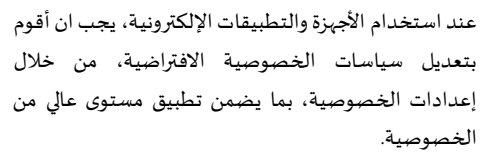 & 5 \\
\hline متوسطة & 14 & $65 \%$ & 1.24 & 3.26 & أُقَّل خدمات الوصول لموقعي بشكلٍٍ مؤقت أثناء استخدام & 15 \\
\hline 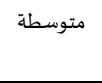 & 15 & $65 \%$ & 1.26 & 3.23 & أستخدم التشفير (من خلال تعيين كلمة مرور) لملفاتي المهمة & 13 \\
\hline عالية & & $72 \%$ & 0.81 & 3.62 & و اقع الأمن السيبر اني في مدارس التعليم العام & المجال ككل \\
\hline
\end{tabular}

يتضح من جدول (6) أن المتوسط العام للمجال الأول "واقع الأمن السيبراني في مدارس التعليم العام بالمدينة المنورة" بلغ (3.62) بانحراف معياري

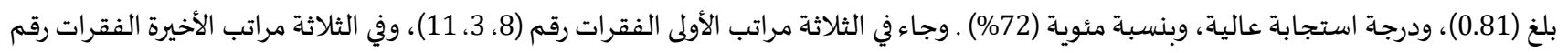

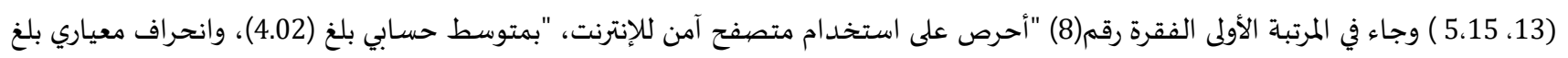

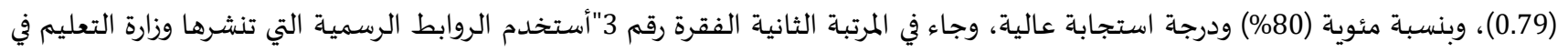

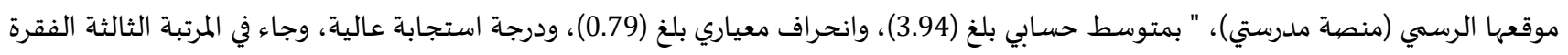

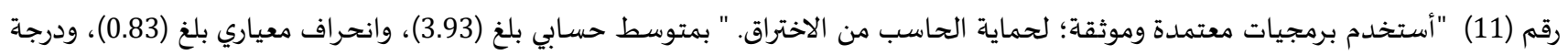

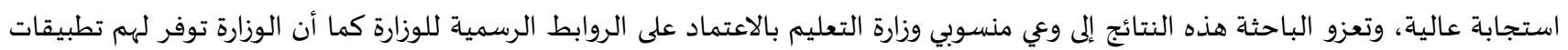


ميكروسوفت الأصلية فلا حاجة لديهم لاستخدام تطبيقات غير أصلية.

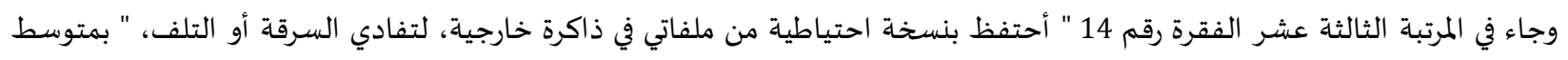
حسابي بلغ (3.35)، وانحراف معياري بلغ (1.21)، ودرجة استجابة متوسطة، وجاء في المرتبة الرابعة عشر الفقرة رقم 5 " عند استخدام الأجهزة

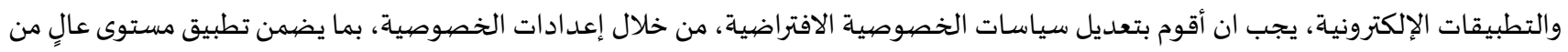
الخصوصياة. " بمتوسط حسابي بلغ (3.33)، وانحراف معياري بلغ (1.16)، ودرجة استجابة متوسطة، وجاء في المرتبة الخامسة عشر الخدر الفقرة رقم 15 "

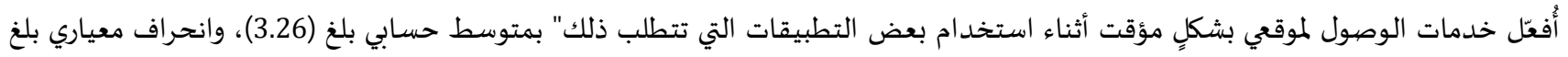

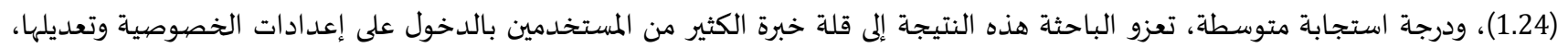

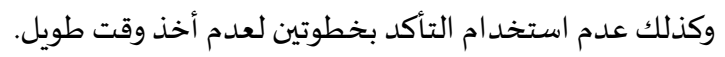

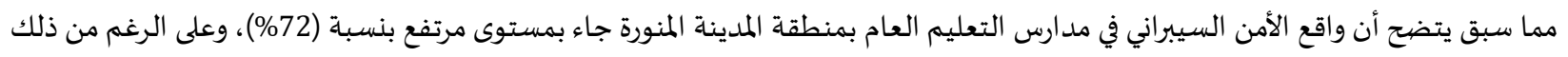

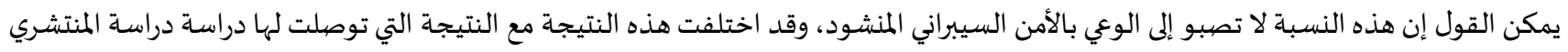

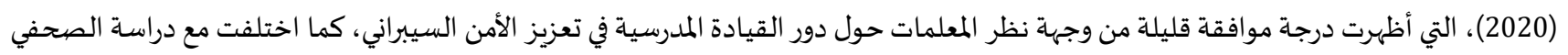

$$
\text { (2019) التي أكدت على وجود ضعف وقصيور لدى معلمات الحاسب الآلي في الوعي بمفاهيم الأمن السيبراني. }
$$

2.3. النتائج المتعلقة بالسؤال الثاني:

للإجابة على هذا السؤال والذي ينص على ما التحديات التي تواجـاء تفعيل الأمن السيبراني في مدارس التعليم العام بمنطقة المدينة المنورة من

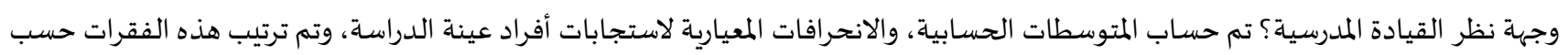

المتوسطات الحسابية تنازليًا.

جدول (7): المتوسطات الحسابية والانحر افات المعيارية والنسبة المئوية لاستجابات أفراد عينة الدراسة على المجال الثاني "التحديات التي تواجه تفعيل الأمن

\begin{tabular}{|c|c|c|c|c|c|c|}
\hline \multicolumn{7}{|c|}{ 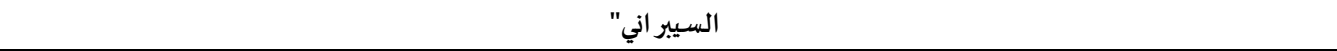 } \\
\hline \multirow[t]{2}{*}{ الاستجابة } & \multirow[t]{2}{*}{ الترتيب } & \multirow{2}{*}{ 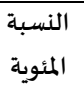 } & \multirow{2}{*}{ 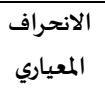 } & المتوسط & \multirow[t]{2}{*}{ 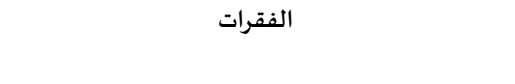 } & \multirow[t]{2}{*}{ 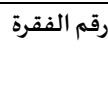 } \\
\hline & & & & 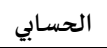 & & \\
\hline عالية جداً & 1 & $86 \%$ & 0.74 & 4.32 & قلة وعي بعض الطلاب حول مخاطر الأمن السيبراني. & 7 \\
\hline \multirow[t]{2}{*}{ عالية جداً } & 2 & $86 \%$ & 0.77 & 4.32 & ضعف السيطرة على الطلاب، ومنعهم من دخول المواقع & 8 \\
\hline & & & & & غير الموثوق بها. & \\
\hline عالية جداً & 3 & $86 \%$ & 0.81 & 4.30 & قلة الوعي بقانون الجرائم المعلوماتية. & 14 \\
\hline \multirow[t]{2}{*}{ عالية جداً } & 4 & $85 \%$ & 0.75 & 4.27 & قلة وجود مختصين في المدراس للتعامل مع مخاطر الأمن & 4 \\
\hline & & & & & 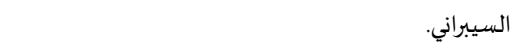 & \\
\hline \multirow[t]{2}{*}{ عالية جداً } & 5 & $85 \%$ & 0.78 & 4.26 & انتشار إعلانات تصيديه تدعي وجود تحديث مجاني ومزيف & 11 \\
\hline & & & & & لمايكروسوفت تيمز (منصة مدرستي). & \\
\hline \multirow[t]{2}{*}{ عالية جداً } & 6 & $85 \%$ & 0.77 & 4.25 & قلة البرامج التدريبية الموجهة للمعنيين بالعملية التعليمية & 9 \\
\hline & & & & & 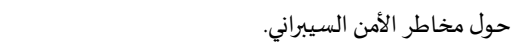 & \\
\hline عالية جداً & 7 & $85 \%$ & 0.76 & 4.25 & انتشار العديد من التطبيقات التعليمية غير الموثوق بها. & 10 \\
\hline 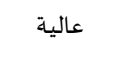 & 8 & $84 \%$ & 0.83 & 4.18 & قلة وعي بعض المعلمين حول مخاطر الأمن السيبراني. & 6 \\
\hline 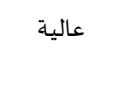 & 9 & $83 \%$ & 0.86 & 4.13 & قلة وعي بعض القادة المدارس حول مخاطر الأمن & 5 \\
\hline \multirow[t]{2}{*}{ عالية } & 10 & $82 \%$ & 0.77 & 4.10 & عدم توفير المدرسة لبرمجيات حماية مواكبة لما يستجد من & 2 \\
\hline & & & & & مخاطر الأمن السيبراني بشكل دوري. & \\
\hline \multirow[t]{2}{*}{ 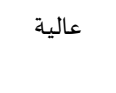 } & 11 & $82 \%$ & 0.77 & 4.08 & ضعف تفعيل آليات التعامل مع مخاطر الأمن السيبراني في & 1 \\
\hline & & & & & 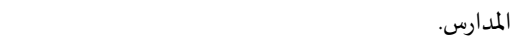 & \\
\hline 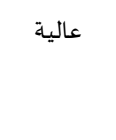 & 12 & $81 \%$ & 0.84 & 4.06 & خاصهاكة بهم من (فيدية المعلمين عن طريق مقتبسة من الدروس) فيديوهات & 12 \\
\hline \multirow[t]{2}{*}{ عالية } & 13 & $77 \%$ & 0.96 & 3.83 & تعرض منصة مدرستي لاختراقات من قبل الطلاب أو من & 3 \\
\hline & & & & & أفراد خارج المدرسة. & \\
\hline \multirow[t]{3}{*}{ عالية } & 14 & $73 \%$ & 1.05 & 3.65 & التعرض إلى تهديدات عبر مواقع التواصل الاجتماعي & 13 \\
\hline & & & & & (واتساب، تويتر، تليجرام، يوتيوب، سناب شات، .... & \\
\hline & & & & & 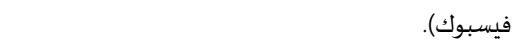 & \\
\hline \multirow[t]{2}{*}{ 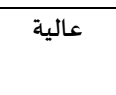 } & & $83 \%$ & 0.64 & 4.14 & التحديات التي تواجه تفعيل الأمن السيبر اني في مدارس & المجال ككل \\
\hline & & & & & التعليم العام بمنطقة المدينة المنورة & \\
\hline
\end{tabular}




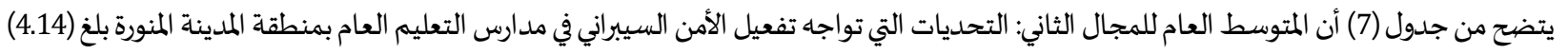

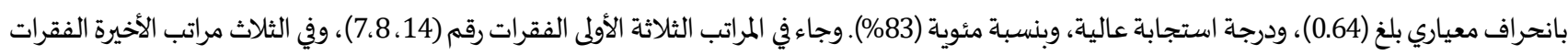

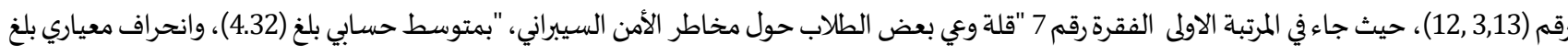

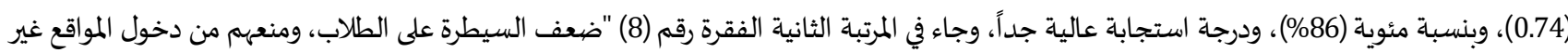

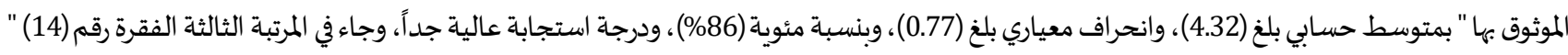

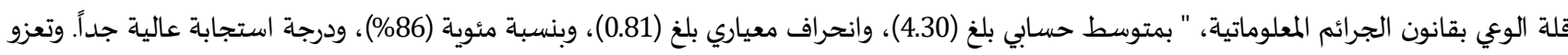

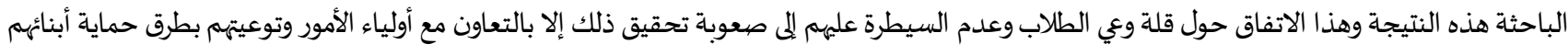

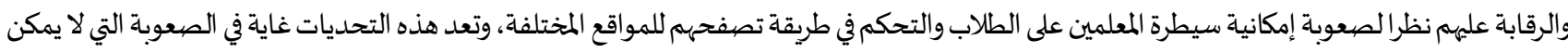
تخطيها إلا بتوعية أولياء الأمور والطالاب معاً.

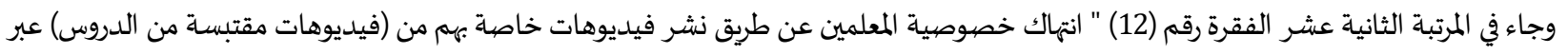

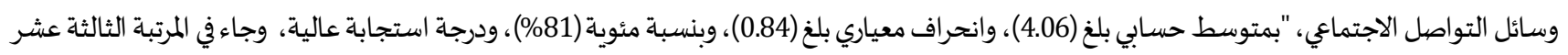

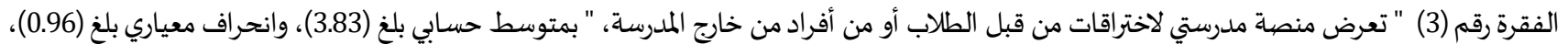

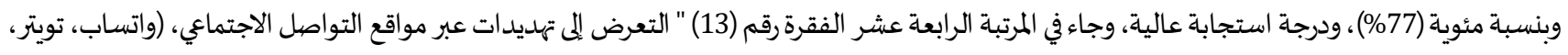

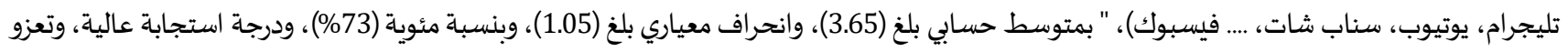

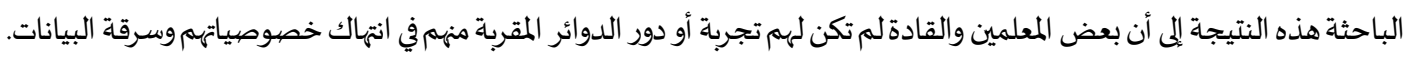

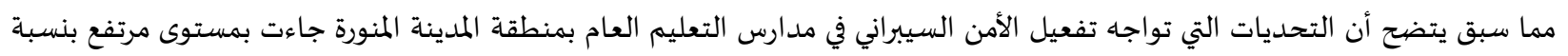

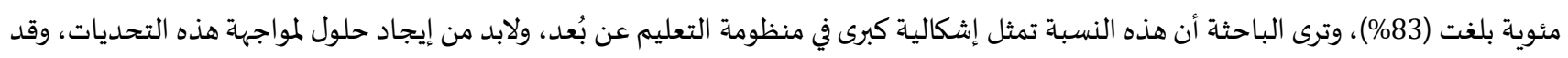

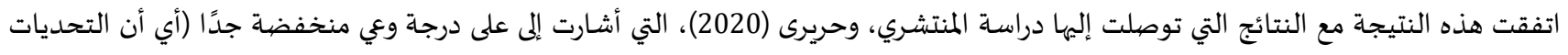

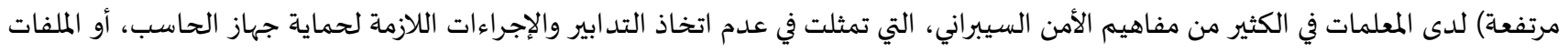

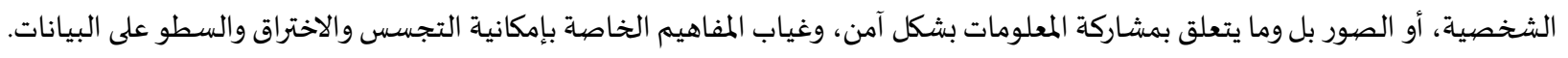

3.3. النتائج المتعلقة بالسؤال الثالث: الزالث:

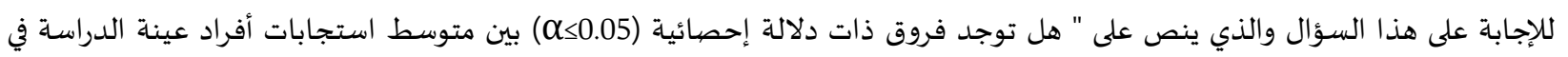

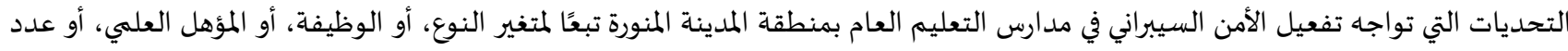

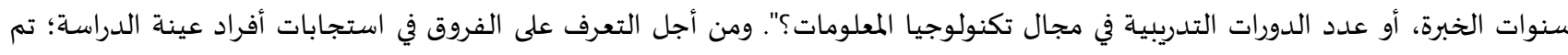

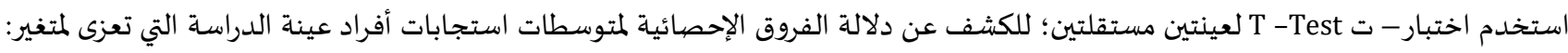

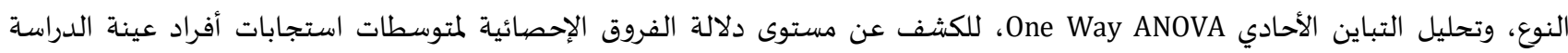

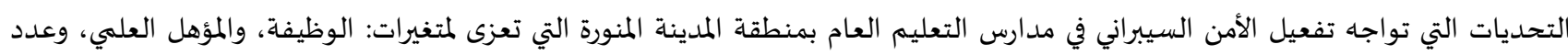

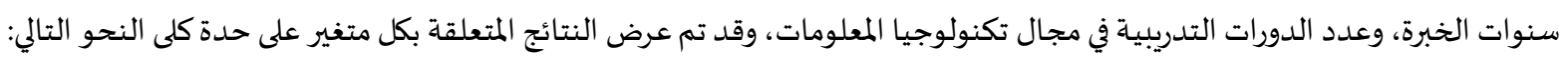
متغير النوع:

جدول (8): نتائج اختبار"ت" (Test) لدلالة الفروق بين متوسطات استجابات أفراد عينة الدراسة على التحديات التي تواجه تفعيل الأمن السيبر اني في مدارس التعليم

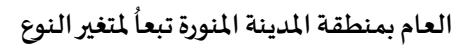

\begin{tabular}{|c|c|c|c|c|c|}
\hline مستوى الدلالة & قيمة & الانحراف المعياري & المتوسط الحسابي & العدد & الفئات \\
\hline & ت & & & & \\
\hline \multirow[t]{2}{*}{0.56} & 0.93 & 0.67 & 4.16 & 223 & ذكور \\
\hline & & 0.62 & 4.12 & 195 & إناث \\
\hline
\end{tabular}

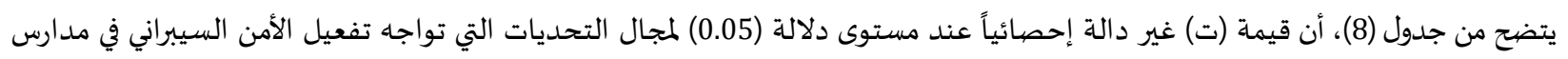

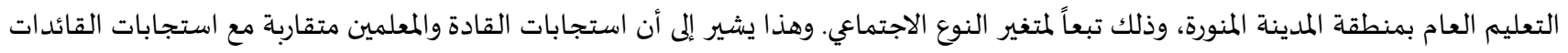

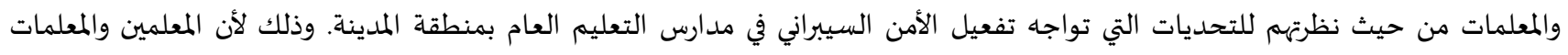

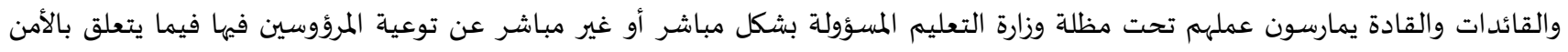

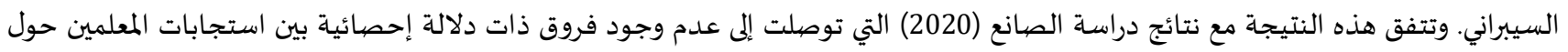

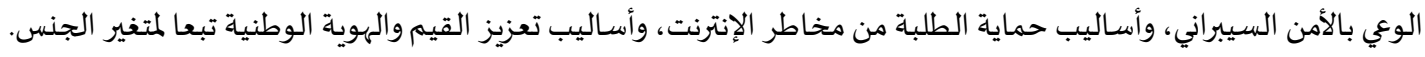


جدول (9): نتائج تحليل التباين الأحادي (One Way ANOVA) لدلالة الفروق بين متوسطات استجابات أفراد عينة الدراسة على التحديات التي تواجه تفعيل الأمن السيبر اني

\begin{tabular}{|c|c|c|c|c|c|}
\hline مستوى & قيمة & متوسط & درجة & مجموع & مصدر \\
\hline الدلالة & ف & المربعات & الحرية & المربعات & التباين \\
\hline \multirow[t]{2}{*}{0.085} & 2.222 & 0.914 & 3 & 2.742 & بين المجموعات \\
\hline & & 0.411 & 414 & 170.286 & داخل المجموعات \\
\hline
\end{tabular}

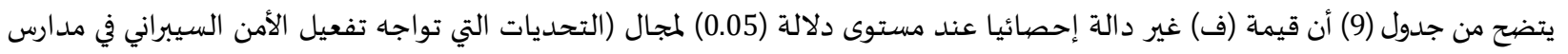

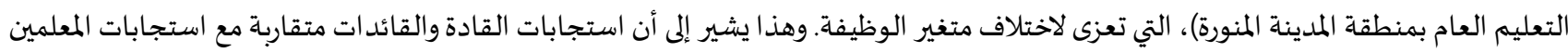

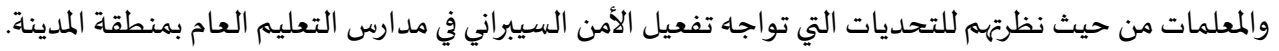

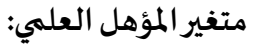

جدول (10): نتائج تحليل التباين الأحادي (One Way ANOVA) لدلالة الفروق بين متوسطات استجابات أفراد عينة الدراسة على التحديات التي تواجه تفعيل الأمن

\begin{tabular}{|c|c|c|c|c|c|}
\hline مستوى & قيمة & متوسط & درجة & مجموع & مصدر \\
\hline الدلالة & ف & المربعات & الحربة & المربعات & التباين \\
\hline \multirow[t]{3}{*}{0.849} & 0.267 & 0.111 & 3 & 0.334 & بين المجموعات \\
\hline & & 0.417 & 414 & 172.694 & داخل المجموعات \\
\hline & & & 417 & 173.028 & المجموع \\
\hline
\end{tabular}

يتضح من جدول (10) أن قيمة (ف) غير دالة إحصائياً عند مستوى دلالة (0.05) لمجال التحديات التي تواجه تفعيل الأمن السيبراني في مدارس

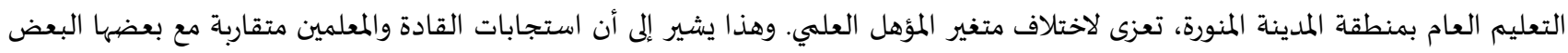

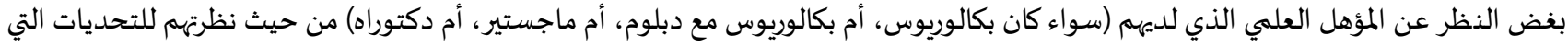

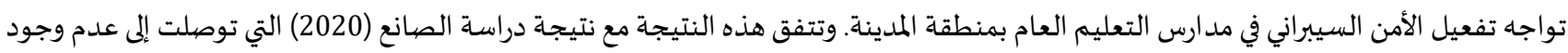
فروق ذات دلالة إحصائية بين استجابات المعلمين حول الوعي بالأمن السيبراني، وأساليب حماية الطلبة من مخاطر الإنترنت، وأساليب تعزيز القيم والهوية الوطنية تبعا لمتغير المؤهل العلمي.

متغير عدد سنوات الخبرة:

جدول (11): نتائج تحليل التباين الأحادي (One Way ANOVA) لدلالة الفروق بين متوسطات استجابات أفراد عينة الدراسة على التحديات التي تواجه تفعيل الأمن السيبر اني

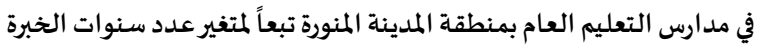

\begin{tabular}{|c|c|c|c|c|c|}
\hline مستوى & قيمة & متوسط & درجة & مجموع & مصدر \\
\hline الدلالة & ف & المربعات & الحرية & المربعات & التباين \\
\hline \multirow[t]{3}{*}{0.485} & 0.725 & 0.301 & 2 & 0.602 & بين المجموعات \\
\hline & & 0.415 & 415 & 172.426 & داخل المجموعات \\
\hline & & & 417 & 173.028 & المجموع \\
\hline
\end{tabular}

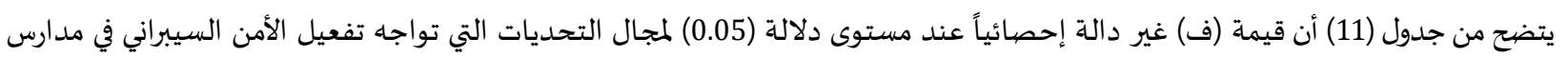

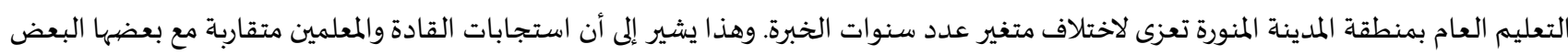

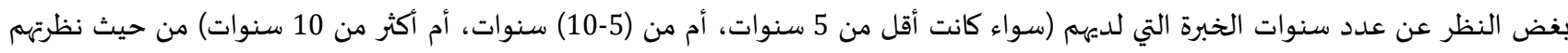

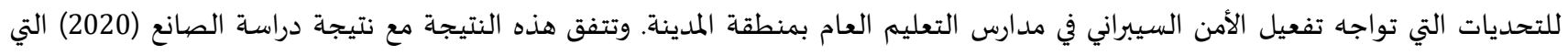
توصلت إلى عدم وجود فروق ذات دلالة إحصائية بين استجابات المعلمين حول الوعي بالأمن السيبراني، وأساليب حماية الطلبة من مخاطر الإنيات الإنترنت، وأساليب تعزيز القيم والهوية الوطنية تبعا لمتغير سنوات الخيات الخبرة.

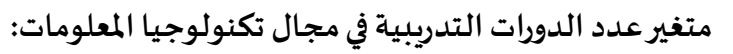


جدول (12): نتائج تحليل التباين الأحادي (One Way ANOVA) لدلالة الفروق بين متوسطات استجابات أفراد عينة الدراسة على التحديات التي تواجه تفعيل الأمن

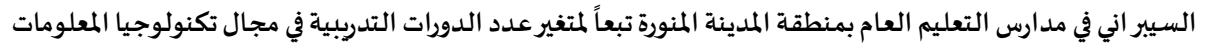

\begin{tabular}{|c|c|c|c|c|c|}
\hline مستوى & قيمة & متوسط & درجة & مجموع & مصدر \\
\hline الدلالة ل & ف & المربعات & الحرية & المربعات & التباين \\
\hline \multirow[t]{3}{*}{0.355} & 1.038 & 0.431 & 2 & 0.861 & بين المجموعات \\
\hline & & 0.415 & 415 & 172.167 & داخل المجموعات \\
\hline & & & 417 & 173.028 & المجمموع \\
\hline
\end{tabular}

يتضح من جدول (12) أن قيمة (ف) غير دالة إحصائياً عند مستوى دلالة (0.05) لمجال التحديات التي تواجه تفعيل الأمن السيبراني في مدارس

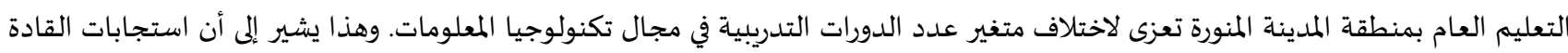

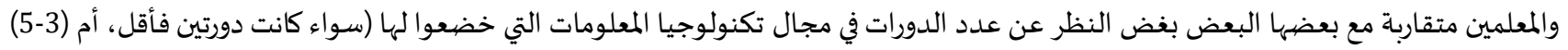

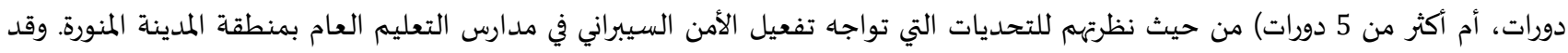

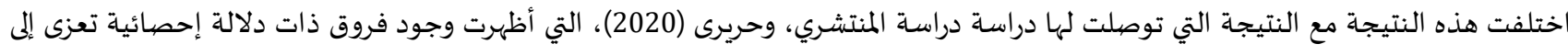

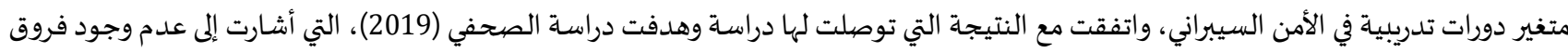

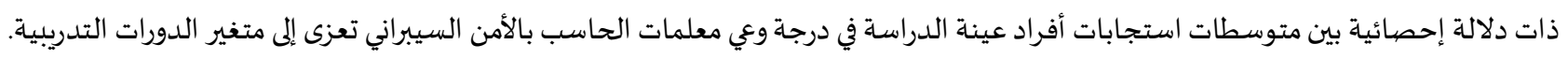

4.3 النتائج المتعلقة بالسؤال الر ابع:

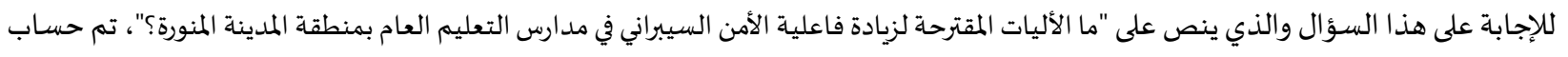

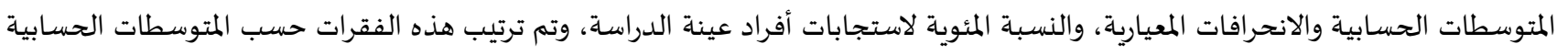
تنازلياً.

جدول (13): المتوسطات الحسابية والانحر افات المعياربة والنسبة المئوية لاستجابات أفراد عينة الدراسة على المجال الثالث (الأليات المقترحة لزيادة فاعلية الأمن السيبر اني في

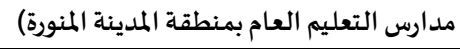

\begin{tabular}{|c|c|c|c|c|c|c|}
\hline الاستجابة & الترتيب & المئوية - النسبة & 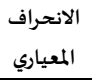 & الحسبط المتوسبي & 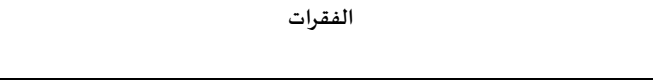 & 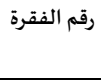 \\
\hline عالية جداً & 1 & $\% 92$ & 0.56 & 4.62 & شبكر الوعي بالأمن السيبراني لدى القيادات والمعلمين والطلاب حول آليات التعامل مع & 5 \\
\hline عالية جداً & 2 & $\% 92$ & 0.54 & 4.62 & تعزيز وعي الطلاب بمخاطر الروابط الضارة عند تصفح الإنترنت. & 9 \\
\hline عالية جداً & 3 & $\% 92$ & 0.57 & 4.62 & مدرسيت دليل تفاعلي عن أخلاقيات الأمن السيبراني، ومفاهيمه لمستخدمي منصبة & 11 \\
\hline عالية جداً & 4 & $\% 92$ & 0.55 & 4.62 & تعريفية موجزة على منصية مدرستي. & 12 \\
\hline عالية جداً & 5 & $\% 92$ & 0.55 & 4.61 & تتعلق بدراستهم. الطلاب بأهمية التحقّق من المصادر الموثوق بها؛ لحصولهم على معلومات & 8 \\
\hline عالية جداً & 6 & $\% 92$ & 0.55 & 4.61 & إرسال رسائل نصية توعوية بمفاهيم ومخاطر وانتهاكات الأمن السيبراني. & 10 \\
\hline عالية جداً & 7 & $\% 92$ & 0.55 & 4.61 & والأساسية إجراءات، وسياسات لحفظ الصادة من الهيئة الوطنية للأمن السيبراني داخل الميبراني. & 13 \\
\hline عالية جداً & 8 & $\% 92$ & 0.57 & 4.61 & توعية منسوبيّ المدرسة بمفاهيم الأمن السيبراني. & 14 \\
\hline عالية جداً & 9 & $\% 92$ & 0.57 & 4.61 & الجرائم المعلوماتية. & 15 \\
\hline عالية جداً & 10 & $\% 92$ & 0.60 & 4.59 & السيبراني. & 4 \\
\hline عالية جداً & 11 & $\% 91$ & 0.60 & 4.57 & توفير برامج توعوية للتعريف بالأمن السيبراني، وآليات تعزيزه في المدارس. & 1 \\
\hline عالية جداً & 12 & $\% 91$ & 0.60 & 4.57 & تشكيل فريق قانوني مختص بقضايا التنمر الإلكتروني عبر منصة مدرستي. & 16 \\
\hline عالية جداً & 13 & $\% 91$ & 0.59 & 4.54 & السيبراني الضيوابط الأساسية في الأمن السيبراني الصادرة من الهيئة الوطنية للأمن & 2 \\
\hline عالية جداً & 14 & $\% 91$ & 0.69 & 4.54 & 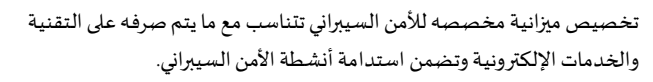 & 17 \\
\hline عالية جداً & 15 & $\% 90$ & 0.62 & 4.52 & السيبراني. & 6 \\
\hline عالية جداً & 16 & $\% 90$ & 0.67 & 4.51 & في المدارسير خبراء ومختصين في الأمن السيبراني؛ لفحص الأجهزة والبرمجيات بصفة دورية & 3 \\
\hline عالية جداً & 17 & $\% 90$ & 0.66 & 4.48 & تضيمين مفاهيم الأمن السيبراني بمقرر تكنولوجيا التعليم ببرامج إعداد المعلمين & 7 \\
\hline \multicolumn{2}{|c|}{ عالية جداً } & $\% 92$ & 0.51 & 4.58 & المدينة المنورة المقترحة لزيادة فاعلية الأمن السيبر اني في مدارس التعليم العام بمنطقة & المجال ككل \\
\hline
\end{tabular}


يتضح من جدول (13) أن المتوسط العام للمجال الثالث (الآليات المقترحة لزبادة فاعلية الأمن السيبراني في مدارس التعليم العام بمنطقة المدينة المنورة)

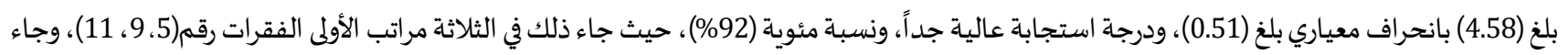

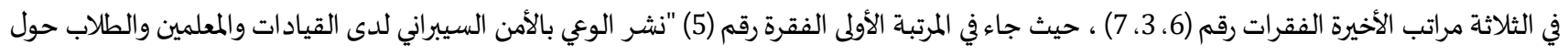

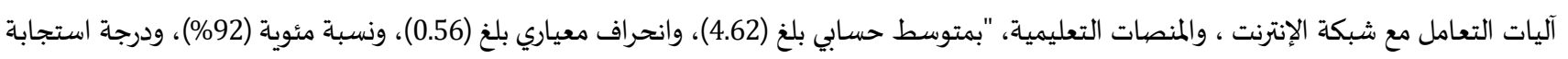

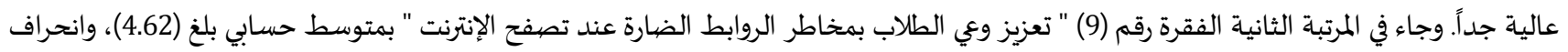

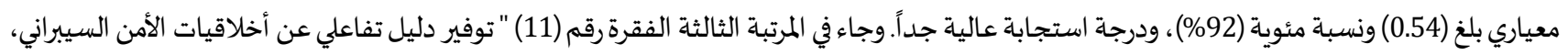

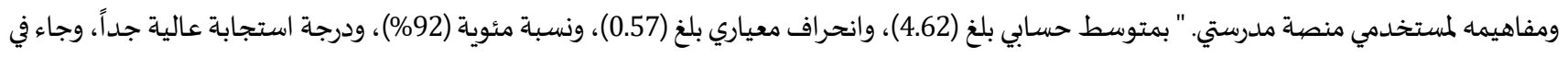

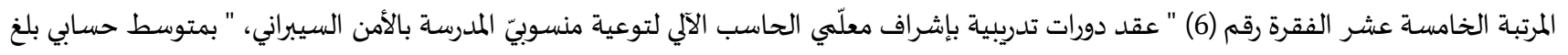

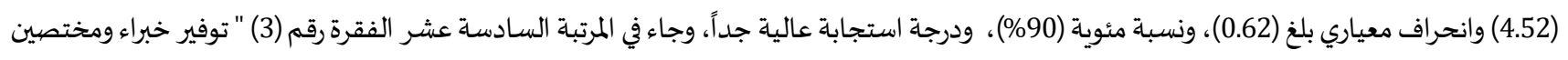

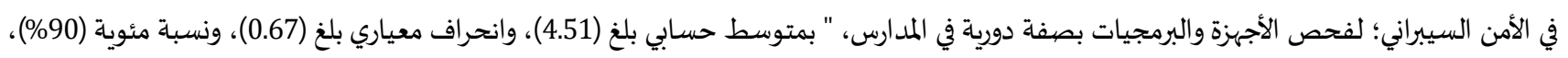

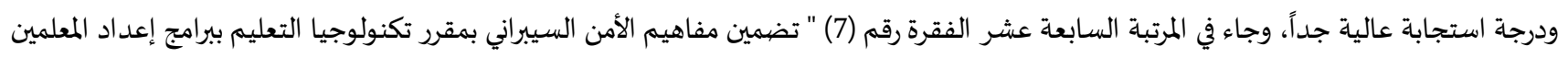

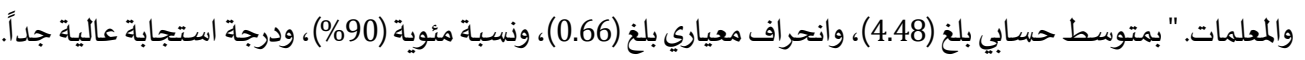

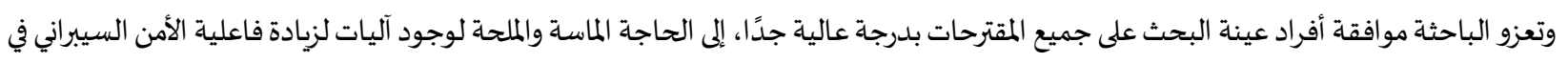

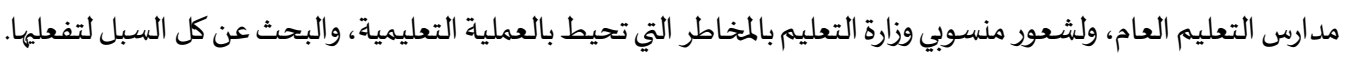

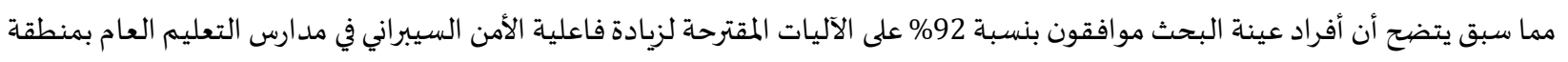
المدينة المنورة.

5.3 التوصيات:

في ضوء النتائج التي توصلت إلهيا الدراسة، تم اقتراح مجموعة من التوصيات على النحو الآتي:

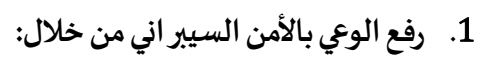

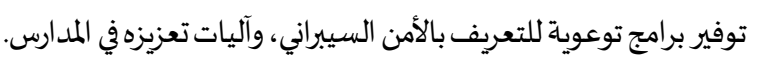
• توعية منسوبيّ المدرسة بمفاهيم الأمن السيبراني.

• نشر الوعي بالأمن السيبراني لدى القيادات والمعلمين والطابل حول آليات الماتئ التعامل مع شبكة الإنترنت والمنصيات التعليمية.

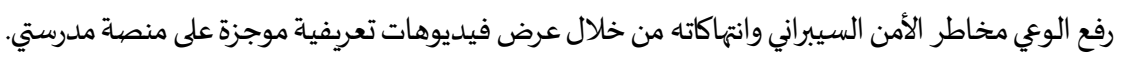

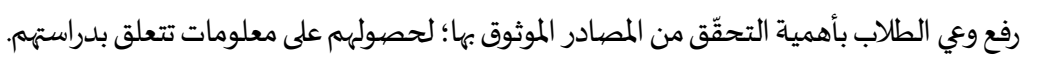

• تعزيز وعي الطلاب بمخاطر الروابط الضارة عند تصفح الإنترنت.

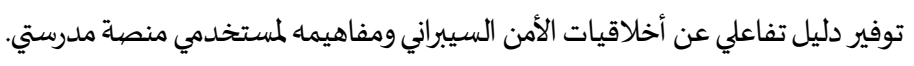
• إرسال رسائل نصية توعوية بمفاهيم الأمن السيبراني ومخاطره وانتهاكاته. • عقد دورات تدرببية بإشراف معلّمي الحاسب الآلي لتوعية منسوبي المدرسة بالأمن السئل السيبراني. • عقد دورات تدريبية بالشراكة مع الجامعات؛ لتوعية منسوبي التعليم العام بالأمن السيبراني.

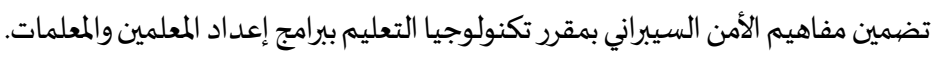
2. تشريع بعض القو انين الخاصة بالأمن السيبر اني من خلال:

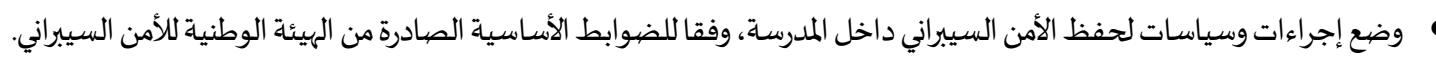

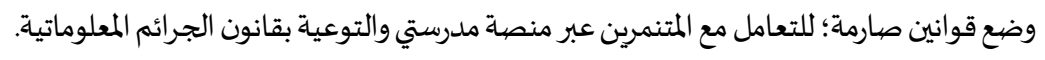
تشكيل فريق قانوني مختص بقضايا التنمر الإلكتروني عبر منصاة مدرستئ.

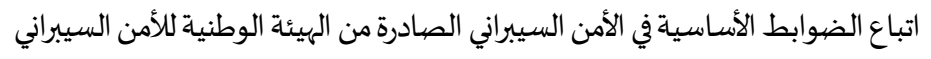

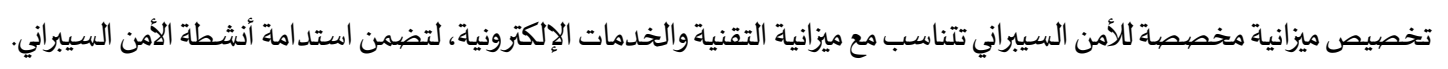

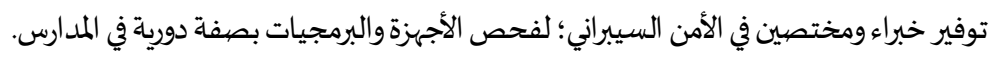

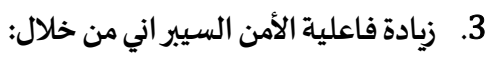
استخدام كلمة مرور معقدة لحسابات الدخول المهمة مثل الدخول لشبكة الوزارة، وينبغي أن تختلف عن كلمات الماتمات المرور المستخدمة في مواقع التواصل الاجتماي او مواقع التسوق الإلكتروني. عدم استخدم البريد الإلكتروني الرسمي في التسجيل والاشتراك في مواقع التواصل الاجتماعي أو التطبيقات. 
ضرورة الاحتفاظ بنسخة احتياطية من الملفات في ذاكرة خارجية؛ لتفادي السرقة أو التلف.

استخدام التشفير (من خلال تعيين كلمة مرور) للملفات المهمة التي يقوم بها منسوبي وزارة التعليم إرسالها من خلال شبكة الإنترنت.

• تعديل سياسات الخصوصية الافتراضية، من خلال إعدادات الخصوصية، بما يضمن تطبيق مستوى عالي من الخصوصية، عند استخدام الأجهزة

والتطبيقات الإلكترونية.

•تفعيل خدمات الوصول للموقع بشكلٍ مؤقت أثناء استخدام بعض التطبيقات التي تتطلب ذلك.

4. العمل على تخطي التحديات التي تواجه تفعيل الأمن السيبر اني في مدارس التعليم العام من خلال:

العمل على زيادةوعي الطلبة حول مخاطر الأمن السيبراني.

إيجاد آلية للسيطرة على الطلاب، ومنعهم من دخول المواقع غير الموثوق بها.

العمل على زيادة الوعي بقانون الجرائم المعلوماتياة.

توفير عدد كافٍ من المختصين في المدراس للتعامل مع مخاطر الأمن السيبراني.

الالتزام بتوجيهات وزارة التعليم وعدم الوقوع في الإعلانات التصيدية التي تديي وجود تحديث مجاني ومنيف لمايكروسوفت تيمز، ومنصية مدرستي.

العمل على زيادة البرامج التدربية الموجهة للمعنيين بالعملية التعليمية حول مخاطر الأمن السيبراني.

عمل قوائم بالتطبيقات التعليمية الموثوق بها، ونشرها على موقع المنصة،، والمراجعة الدورية لتلك التطبيقات لرصدد سلوكها.

6.3. المقترحات:

إجراء دراسة مماثلة للدراسة الحالية في مختلف إدارات التعليم بالمملكة العربية السعودية.

إجراء دراسة مماثلة للدراسة الحالية على جامعات المملكة العربية السعودية.

إجراء دراسة حول العلاقة بين الوعي بالأمن السيبراني والثقافة التكنولوجية لدى المعلمين.

المراجع:

أولاً: المراجع العربية:

1. بونيف، سامي (2019). دور الإستراتيجيات الاستباقية في مواجهة الهجماتهات السيبرانية: الردع السيبراني أنموذجا. المجلة الجزائرية للحقوق

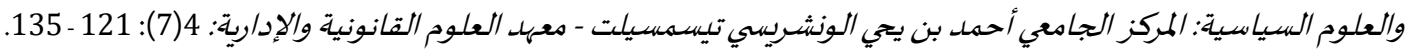

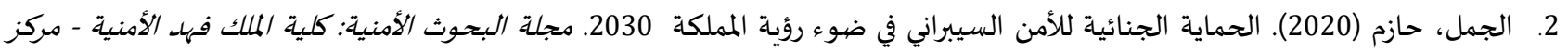

الدراسات

3. حيمد، محمد (2019). رؤية إستراتيجية لمكافحة الجرائم السيبرانية: اليمن دراسة حالة. المجلة العبرية الدولية للمعلوماتية: اتحاد الجامعات

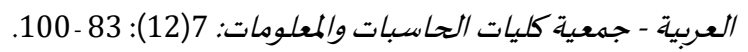

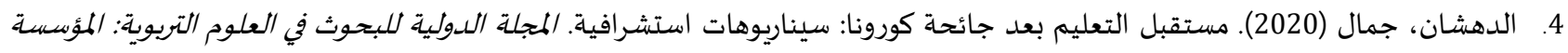

الدولية لآفاق المستقبل، 3(4): 105 - 169.

5. الراظمي، سيدي (2019). الجريمة السيبرانية وتكاملية النص الوطني، الإقليمي والدولي. مجلة القانون والأعمال: جامعة الحسن الأول - كلية

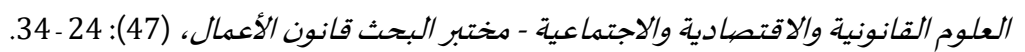

6.

للعلوم الأمنية، 30(61): 157 - 192.

7. السرحان، حنين؛ المشاقبة، محمد (2020). أثر تطبيق سياسة الأمن السيبراني على جودة المعلومات المحاسبية في البنوك التحجارية الأردنية

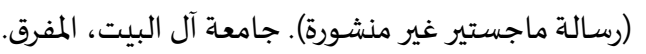

8. سليمان، أمين؛ أبو علام، رجاء (2010). القياس والتقويهر في العلوم الإنسانية أسسه وأدواته وتطبيقاته. القاهرة، دار الكتاب الحديث.

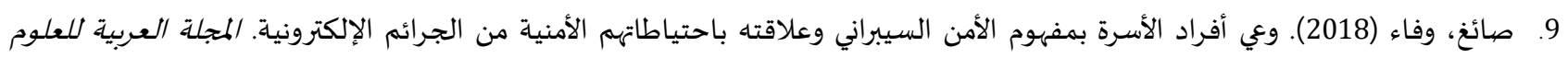

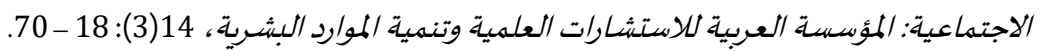

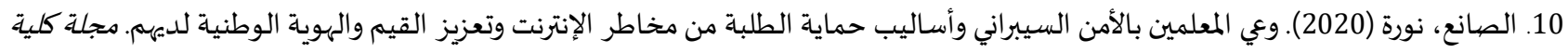
التوبية: جامعة أسيوط - كلية التربية، 36 (6): 41 - 90.

11. الصحفي، مصبباح (2019). مستوى الوعي بالأمن السيبراني لـدى معلمات الحاسب الآلي للمرحلة الثانويـة بمدينة جدة. مجلة البحث العلهي في 
التوبية؛ جامعة عين شمس - كلية البنات للآداب والعلوم والتربية، 20(10): 493 - 534.

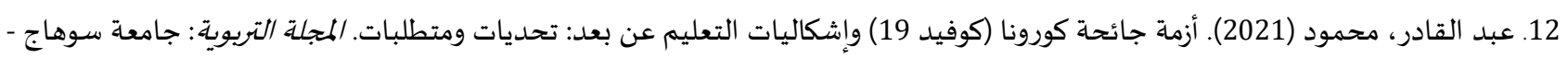

$$
\text { كلية التربية، (83): } 1 \text { - } 17 .
$$

13. عبيدات، ذوقان (2011). البحث العلهي مفهوهه وأدواته وأساليبه ، عمان: دار التهبية، الفكر للنشر والتوزيع.

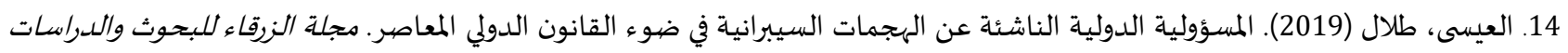

الإنسانية: جامعة الزرقاء - عمادة البحث العلهي، 19 (1): 81 - 95.

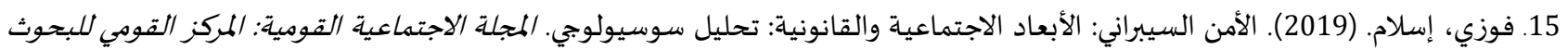

الاجتماعية والجنائية، $56(2)$ (2): 99 - 139.

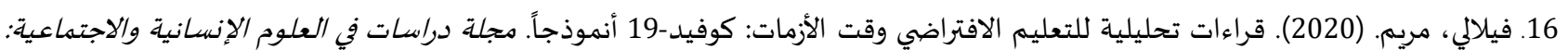

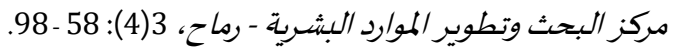

17. مانيطه، يوسف (2017). نظرة عامة عن الجريمة الإلكترونية في الفضاء السيبراني. المجلة الليبية العالمية: جامعة بنغازي-كلية التوبية بالمبه،

18. محمود، عبد الرازق (32020). تطبيقات الذكاء الاصطناعي: مدخل لتطوير التعليم في ظل تحديات جائحة فيروس كورونا (COVID-19). المجلة

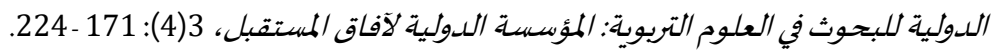

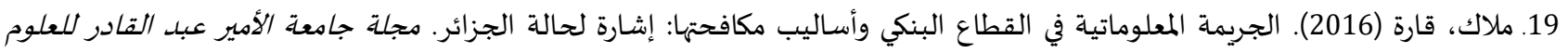

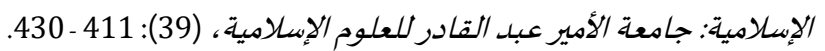

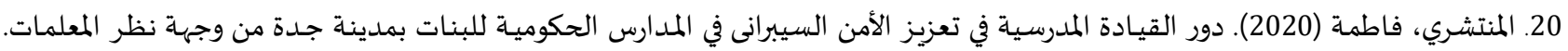

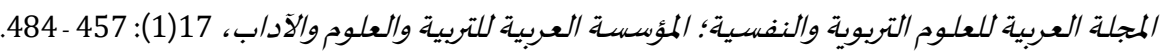

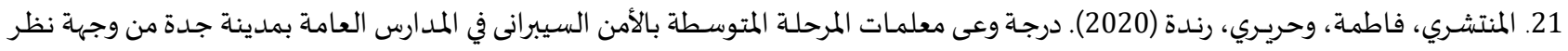

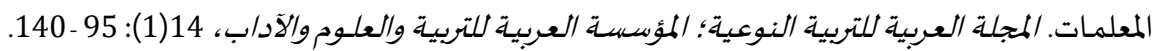

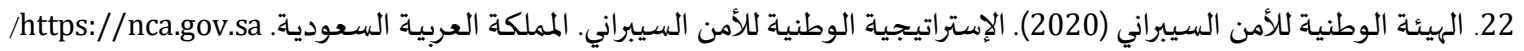

23. وزارة التعليم (2020). المملكة العربية السعودية.

24. وزارة التعليم (2020). المملكة العربية السعودية.

25. يوسف، يوسف (2020). اتجاهات الطلاب نحو التعليم الإلكتروني في ظل جائحة فيروس كورونا: دراسة تطبيقية على عينة من طلاب كلية

الاتصال والإعلام بجامعة الملك عبد العزيز بجدة. مجلة الحكمة للدراسات الإعلامية والاتصبالية: (21): 11 ـ 37.

ثانياً: المراجع الأجنبية:

1. Alexander, R. T. (2017). Can the analytical hierarchy process model be effectively applied in the prioritization of information assurance defense in-depth measures? -a quantitative study (Doctoral dissertation, Capella University).

2. Bhatnagar, N., \& Pry, M. (2020). Student Attitudes, Awareness, and Perceptions of Personal Privacy and Cybersecurity in the Use of social media: An Initial Study. Information Systems Education Journal, 18(1): 48-58.

3. Chapman, J. (2019). How Safe is Your Data?: Cyber-security in Higher Education. Higher Education Policy Institute.

4. Corrigan, L., \& Robertson, L. (2015). Inside the Digital Wild West: How School Leaders Both Access and Avoid social media. International Association for Development of the Information Society.

5. Frydenberg, M., \& Lorenz, B. (2020). Lizards in the Street! Introducing Cybersecurity Awareness in a Digital Literacy Context. Information Systems Education Journal, 18(4): 33-45.

6. Gleeson, H. (2014). The prevalence and impacts of bullying linked to social media on the mental health and suicidal behavior among young people: A review of the literatures,7,14-16. https://www.education.ie/en/Publications/Educationeports/The-Preva- lence-and-Impact-of-Bullying-linked-to-Social-Media-on-the-Mental- Health-and-Suicidal-Behaviuor-Among-YoungPeople.pdf

7. Kurtz, H., Lloyd, S., Harwin, A., \& Osher, M. (2018). School Leaders and Technology: Results from a National Survey. Editorial Projects in Education. 


$$
\text { المجلة الدولية للدراسات التربوية والنفسية }
$$

International Journal of Educational \& Psychological Studies (EPS) Journal Homepage: https://www.refaad.com/views/EPSR/Home.aspx www.refaad.com

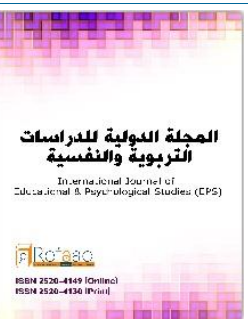

\title{
The reality of cyber security and increasing its effectiveness in public education schools in Al-Madinah Al-Munawwarah region from the point of view of the school leadership
}

\author{
Mashael Shabib Mutairan AlZuwifri AlMutairi \\ Master's in Education Economics and Planning, Ministry of Education, KSA \\ mashael1alzuwifri@outlook.sa
}

\author{
Received : 8/7/2021 Revised : 20/7/2021 Accepted : 12/8/2021 DOI : https://doi.org/10.31559/EPS2021.10.3.7
}

\begin{abstract}
The study aimed to identify the reality of cyber security and increasing its effectiveness in public education schools in Al-Madinah Al-Munawwarah region from the point of view of the school leadership. To achieve the aim of the study, the descriptive and analytical approach was used, and a questionnaire was designed and distributed to a randomly selected sample from the study population of the study represented by leaders and teachers in public education schools in Madinah, Saudi Arabia, and the final sample reached (418). The study reached a set of findings, the most important of which were: Cybersecurity in public education schools in the Medina came at a high level of $(72 \%)$ and it was found that there are many challenges facing the activation of cybersecurity in public education schools in the Madinah, which came at a high level with a percentage of (83\%). The results of the study also indicated that there were no statistically significant differences at a significance level $(0.05)$ for the challenges facing the activation of cybersecurity in public education schools in the Madinah due to the different variables of gender, job, academic qualification, number of years of experience, number of training courses in the field of information technology. As the study concluded the agreement of (92\%) of the study sample on the proposed mechanisms to increase the effectiveness of cybersecurity in public education schools in Al Madinah Al Munawara; on top of which was: spreading awareness of cybersecurity among leaders, teachers, and students about the mechanisms of dealing with the Internet and educational platforms and enhancing students' awareness of the dangers of harmful links when surfing the Internet. As well as providing an interactive guide on cybersecurity ethics and its concepts for users of Madrasati platform. The study recommends that school staff should use a complex password for important log-in accounts, such as entering the Ministry's network. Furthermore, refraining from the use of the official e-mail to register and subscribe to social networking sites or electronic applications.
\end{abstract}

Keywords: Distance Education; Madrasati Platform; Cybersecurity.

\section{References:}

1. 'bd Alqadr, Mhmwd (2021). Azmh Ja'ht Kwrwna (Kwfyd 19) Weshkalyat Alt'lym 'n B'd: Thdyat Wmttlbat. Almjlh Altrbwyh: Jam't Swhaj - Klyt Altrbyh, (83): 1 - 17.

2. 'bydat, Dwqan (2011). Albhth Al'Imy Mfhwmh Wadwath Wasalybh, 'man: Dar Alfkr Llnshr Waltwzy'.

3. Al'ysa, Tlal (2019). Alms'wlyh Aldwlyh Alnash'h 'n Alhjmat Alsybranyh Fy Dw' Alqanwn Aldwly Alm'asr. Mjlt Alzrqa' Llbhwth Waldrasat Alensanyh: Jam't Alzrqa' - 'madh Albhth Al'lmy, 19(1): 81 - 95.

4. Bwnyf, Samy (2019). Dwr Alestratyjyat Alastbaqyh Fy Mwajht Alhjmat Alsybranyh: Alrd' Alsybrany Anmwdja. Almjlh Aljza'ryh Llhqwq Wal'lwm Alsyasyh: Almrkz Aljam'y Ahmd Bn Yhy Alwnshrysy Tysmsylt - M'hd Al'lwm Alqanwnyh Waledaryh: 4(7): 121 - 135.

5. Aldhshan, Jmal (2020). Mstqbl Alt'lym B'd Ja'ht Kwrwna: Synarywhat Astshrafyh. Almjlh Aldwlyh Llbhwth Fy Al'lwm Altrbwyh: Alm'ssh Aldwlyh Lafaq Almstqbl, 3(4): 105 - 169.

6. Fwzy, Eslam. (2019). Alamn Alsybrany: Alab'ad Alajtma'yh Walqanwnyh: Thlyl Swsywlwjy. Almjlh Alajtma'yh Alqwmyh: Almrkz Alqwmy Llbhwth Alajtma'yh Waljna'yh, 56(2): 99 - 139.

7. Fylaly, Mrym. (2020). Qra'at Thlylyh Llt'lym Alaftrady Wqt Alazmat: Kwfyd-19 Anmwdjaan. Mjlt Drasat Fy Al'lwm Alensanyh Walajtma'yh: Mrkz Albhth Wttwyr Almward Albshryh - Rmah, 3(4): 58 - 98.

8. Alhy'h Alwtnyh Llamn Alsybrany (2020). Alestratyjyh Alwtnyh Llamn Alsybrany. Almmlkh Al'rbyh Als'wdyh. https://nca.gov.sa/ 
9. Hymd, Mhmd (2019). R'yh Estratyjyh Lmkafht Aljra'm Alsybranyh: Alymn Drash Halh. Almjlh Al'rbyh Aldwlyh Llm'lwmatyh: Athad Aljam'at Al'rbyh - Jm'yt Klyat Alhasbat Walm'lwmat: 7(12): 83 - 100.

10. Aljml, Hazm (2020). Alhmayh Aljna'yh Llamn Alsybrany Fy Dw' R'yt Almmlkh 2030. Mjlt Albhwth Alamnyh: Klyt Almlk Fhd Alamnyh - Mrkz Aldrasat

11. Manyth, Ywsf (2017). Nzrh 'amh 'n Aljrymh Alelktrwnyh Fy Alfda' Alsybrany. Almjlh Allybyh Al'almyh: Jam't BnghazyKlyt Altrbyh Balmrj, (32): 1- 10.

12. Mhmwd, 'bd Alrazq (2020). Ttbyqat Aldka' Alastna'y: Mdkhl Lttwyr Alt'lym Fy Zl Thdyat Ja'ht Fyrws Kwrwna (Covid-19). Almjlh Aldwlyh Llbhwth Fy Al'lwm Altrbwyh: Alm'ssh Aldwlyh Lafaq Almstqbl, 3(4): 171 - 224.

13. Mlak, Qarh (2016). Aljrymh Alm'lwmatyh Fy Alqta' Albnky Wasalyb Mkafhtha: Esharh Lhalh Aljza'r. Mjlt Jam't Alamyr 'bd Alqadr Ll'lwm Aleslamyh: Jam't Alamyr 'bd Alqadr Ll'lwm Aleslamyh, (39): 411 - 430.

14. Almntshry, Fatmh (2020). Dwr Alqyadh Almdrsyh Fy T'zyz Alamn Alsybrana Fy Almdars Alhkwmyh Llbnat Bmdynh Jdh Mn Wjht Nzr Alm'lmat. Almjlh Al'rbyh Ll'lwm Altrbwyh Walnfsyh: Alm'ssh Al'rbyh Lltrbyh Wal'lwm Waladab, 17(1): 457 $-484$.

15. Almntshry, Fatmh, Whryry, Rndh (2020). Drjt W'a M'lmat Almrhlh Almtwsth Balamn Alsybrana Fy Almdars Al'amh Bmdynh Jdh Mn Wjht Nzr Alm'Imat. Almjlh Al'rbyh Lltrbyh Alnw'yh: Alm'ssh Al'rbyh Lltrbyh Wal'lwm Waladab, 14(1): $95-140$.

16. Alrazmy, Sydy (2019). Aljrymh Alsybranyh Wtkamlyh Alns Alwtny, Aleqlymy Waldwly. Mjlt Alqanwn Wala'mal: Jam't Alhsn Alawl - Klyt Al'lwm Alqanwnyh Walaqtsadyh Walajtma'yh - Mkhtbr Albhth Qanwn Ala'mal, (47): 24 - 34.

17. Alrdfany, Mhmd (2014). Thqyqat Alshrth Fy Mwajhh Thdyat Aljra'm Alsybranyh. Almjlh Al'rbyh Lldrasat Alamnyh: Jam't Nayf Al'rbyh Ll'lwm Alamnyh, 30(61): 157 - 192.

18. Sa'gh, Wfa' (2018). W'y Afrad Alasrh Bmfhwm Alamn Alsybrany W'laqth Bahtyatathm Alamnyh Mn Aljra'm Alelktrwnyh. Almjlh Al'rbyh Ll'lwm Alajtma'yh: Alm'ssh Al'rbyh Llastsharat Al'lmyh Wtnmyh Almward Albshryh, 14(3): 18 - 70.

19. Alsan', Nwrh (2020). W'y Alm'Imyn Balamn Alsybrany Wasalyb Hmayt Altlbh Mn Mkhatr Alentrnt Wt'zyz Alqym Walhwyh Alwtnyh Ldyhm. Mjlt Klyt Altrbyh: Jam't Asywt - Klyh Altrbyh, 36(6): 41 - 90.

20. Alshfy, Msbah (2019). Mstwa Alw'y Balamn Alsybrany Lda M'lmat Alhasb Alaly Llmrhlh Althanwyh Bmdynh Jdh. Mjlt Albhth Al'Imy Fy Altrbyh: Jam't 'yn Shms - Klyt Albnat Lladab Wal'lwm Waltrbyh, 20(10): 493 - 534.

21. Slyman, Amyn: Abw 'lam, Rja' (2010). Alqyas Waltqwym Fy Al'lwm Alensanyh Assh Wadwath Wttbyqath. Alqahrh, Dar Alktab Alhdyth.

22. Alsrhan, Hnyn: Almshaqbh, Mhmd (2020). Athr Ttbyq Syast Alamn Alsybrany 'la Jwdh Alm'lwmat Almhasbyh Fy Albnwk Altjaryh Alardnyh (Rsalt Majstyr Ghyr Mnshwrh). Jam't Al Albyt, Almfrq.

23. Wzart Alt'lym (2020). Almmlkh Al'rbyh Als'wdyh. https://www.moe.gov.sa

24. Wzart Alt'lym (2020). Almmlkh Al'rbyh Als'wdyh. https://www.moe.gov.sa/ar/pages/default.aspx.

25. Ywsf, Ywsf (2020). Atjahat Altlab Nhw Alt'lym Alelktrwny Fy Zl Ja'ht Fyrws Kwrwna: Drash Ttbyqyh 'la 'ynh Mn Tlab Klyt Alatsal Wale'lam Bjam't Almlk 'bd Al'zyz Bjdh. Mjlt Alhkmh Lldrasat Ale'lamyh Walatsalyh: (21): 11 - 37. 